Mapping Concepts to Locate Learning Opportunities: Aligning the ACRL Framework to the GIS\&T Body of Knowledge

Joshua Sadvari

University Libraries, The Ohio State University, Columbus, Ohio, United States

Address correspondence to Joshua Sadvari, University Libraries, The Ohio State University, Columbus, OH 43210, USA. E-mail: sadvari.1@,osu.edu

ORCID iD: https://orcid.org/0000-0003-3842-9905

Twitter:@GISjsadvari (https://twitter.com/GISjsadvari)

This is an Accepted Manuscript of an article published by Taylor \& Francis in the Journal of Map \& Geography Libraries on 24 February 2020, available online: https://www.tandfonline.com/10.1080/15420353.2020.1719270. 


\title{
Mapping Concepts to Locate Learning Opportunities: Aligning the ACRL Framework to the GIS\&T Body of Knowledge
}

\author{
The adoption of the Association of College and Research Libraries (ACRL) \\ Framework for Information Literacy for Higher Education in 2016 coincided \\ with the launch of the digital edition of the Geographic Information Science and \\ Technology (GIS\&T) Body of Knowledge. The GIS\&T Body of Knowledge and \\ the ACRL Framework share a common goal of providing a flexible, community- \\ driven, living document to support teaching and learning in higher education. The \\ Body of Knowledge serves as a representation of the GIS\&T knowledge domain, \\ while the ACRL Framework aids librarians in integrating core information \\ literacy concepts into instruction in their respective knowledge domains. Despite \\ this connection, no attempt to evaluate how these guiding documents can be \\ aligned to one another to inform instructional practice has yet been reported. This \\ study uses a relative crosswalk approach to map connections between the \\ knowledge practices and dispositions in the ACRL Framework and the learning \\ objectives in the GIS\&T Body of Knowledge. This analysis highlights alignment \\ between these documents and can serve as a conceptual foundation to make it \\ easier for map, geospatial, and subject librarians to identify practical \\ opportunities for integrating information literacy instruction into GIS\&T \\ education, both independently and in collaboration with disciplinary faculty.
}

Keywords: information literacy, ACRL Framework, GIS, Body of Knowledge, geospatial education 


\section{Introduction}

Academic libraries across institutions of various types and sizes are increasingly recognizing the demand for, and engaging in, the delivery of services and support related to geographic information systems (GIS) and mapping. Over the last two decades, the geospatial services offered by libraries have increased in both breadth and depth, though variation exists across this landscape based on factors such as institutional context and organizational capacities (Holstein 2015; March and Scarletto 2017).

Recent studies of the geospatial services landscape in academic libraries have focused on topics including the evolution of services over time (March and Scarletto 2017), service models and offerings (Holstein 2015; March 2011), assessing user needs for specific areas (Scarletto 2013), and addressing challenges associated with maintaining a relevant suite of resources and services in the continually changing environment of geospatial technologies (LaLonde and Piekielek 2018).

While education and training activities are often noted as one component of a broader suite of geospatial support in academic libraries, much of this discussion has focused on instructional concerns such as topics and technologies of interest, coverage level (i.e., basic vs. in-depth), target audience (i.e., broad vs. discipline-specific), and modes of delivery. There are relatively few examples in the library and information science literature discussing the potential for directly integrating information literacy concepts into libraries' geospatial education offerings (e.g., Dodsworth and Laliberté 2016; Jablonski 2004; Kong et al. 2017). Despite this gap, librarians may be particularly well-suited to advance learning in a domain that spans the many different sources, types, uses, communication modes, and cross-disciplinary applications of geographic information. 
The main goals of the present study are to illustrate the natural connections between information literacy and geographic information science and technology (GIS\&T), and to advance conversations around strategies for integrating information literacy concepts into the geospatial education activities offered by academic libraries, both independently and in collaboration with disciplinary faculty. This study will be particularly useful to librarians seeking to develop learning objectives that bridge information literacy and geospatial concepts, as well as those engaging in conversations with disciplinary faculty around integrating information literacy instruction into the curriculum. I approach the goals articulated above through the examination and alignment of two guiding documents in the domains of librarianship and GIS\&T, respectively, the Association of College and Research Libraries (ACRL) Framework for Information Literacy for Higher Education (ACRL 2015) and the Geographic Information Science and Technology Body of Knowledge (DiBiase et al. 2006; UCGIS n.d.). After a brief review of the literature regarding information literacy and geospatial education, I will discuss each of these guiding documents in more detail.

\section{Information Literacy and Geospatial Education}

As defined in the ACRL Framework for Information Literacy for Higher Education (hereafter the Framework),

\footnotetext{
"information literacy is the set of integrated abilities encompassing the reflective discovery of information, the understanding of how information is produced and valued, and the use of information in creating new knowledge and participating ethically in communities of learning" (ACRL 2015, 8).
}

There are a number of discussions of information literacy concepts in geospatial education that pre-date the publication of the Framework, including several that call attention to successful collaborations between geography faculty and librarians. Krygier 
and Peoples (2003) offer an inspiring example of a faculty/librarian collaboration to enhance an introductory course ("The Power of Maps and GIS") at Ohio Wesleyan University. The authors note how the integration of geographic information literacy with information literacy education more broadly not only benefits students, but disciplinary faculty and librarians as well. Geospatial educators can draw from the latest ideas and best practices for information literacy education articulated by librarians, while also increasing the attention paid toward maps and geographic information as a special subset of information literacy (ibid.). Kimsey and Cameron (2005) detail an example of collaboratively integrating information literacy instruction into the geography curriculum at James Madison University, including the development of information literacy learning objectives for geography majors and the process for assessing achievement of those learning objectives.

Elsewhere in the library and information science literature, Jablonski (2004) outlines a "train the trainer" model for incorporating information literacy concepts more explicitly into the teaching of GIS, specifically in the area of training students how to find and prepare geospatial data for use in course projects. Nazari $(2011 ; 2016)$ details a contextual model for uncovering and understanding the information literacy needs of students in an online distance learning geographic information science/systems program, discussing the process through which the students experience information literacy, and highlighting key characteristics and requirements of university GIS assignments and their relationship to information literacy needs.

Following the publication of the Framework, Dodsworth and Laliberté (2016) discuss examples of how spatial literacy, in particular the concepts of location, distance, and scale, can be approached through each of the six frames that comprise the Framework. Specific examples of connections between information and spatial literacy 
concepts are discussed in the context of one-shot classroom instruction opportunities, while guidance on the objectives and structure for a semester-long introductory GIS course for library and information science students is also provided (ibid.). In another recent example, Kong et al. (2017) demonstrate how the integration of information literacy, spatial literacy, and the digital humanities characterized the instructional design process for a National Endowment for the Humanities (NEH)-funded summer institute. The authors conclude with a discussion of how the Framework served as a flexible guide for collaborative instructional design for the summer institute, and they highlight broader opportunities for the Framework to influence instruction for GIS and the digital humanities (ibid).

Information literacy has also been a topic of conversation in the geography and GIS\&T education literature, often with reference to information literacy as a key component of the general education curriculum. DiBiase $(1996,62)$ provides a detailed overview of the rationale for, and development of, an introductory course ("Mapping Our Changing World") at Pennsylvania State University focused on "students' understanding of, and ability to articulate, the unique properties of geographic information and the social contexts in which it is produced and used," a scope which emphasizes the importance of information literacy for geospatial education. More recently, Hamerlinck (2015) discusses a course redesign experience at the University of Wyoming with the goal of creating an introductory GIS\&T course that maintains a focus on map use concepts and skills, while also serving as an information literacy general education option and a gateway for more advanced coursework in GIS and remote sensing. Many of us may recognize courses with a similar goal and scope, but varied titles (e.g., "Mapping Our World," "Mapping a Changing World," "Digital 
Mapping," "Maps, Geospatial Technology, and Spatial Reasoning”), at our own institutions (ibid).

This brief review highlights prior studies focused on the potential integration of information literacy concepts into geospatial education from a variety of perspectives in both the library and information science and geography education literature. While introductory general education courses are an essential area in which academic librarians and disciplinary faculty can (and do) collaborate to integrate information literacy instruction into GIS\&T curricular learning objectives, the results of this study will illustrate that numerous other opportunities for integration exist elsewhere in the curriculum, across disciplines, and in the creation of library-based educational content. These opportunities emerge from aligning guiding documents aimed at both librarians and GIS\&T educators and practitioners, namely the Framework and the GIS\&T Body of Knowledge.

\section{ACRL Framework for Information Literacy for Higher Education}

The Framework (ACRL 2015) was officially adopted by the ACRL Board in 2016, replacing the Information Literacy Competency Standards for Higher Education (hereafter the Standards, ACRL 2000), which were rescinded later that year. Through the Framework, information literacy is envisioned as "an overarching set of abilities in which students are consumers and creators of information who can participate successfully in collaborative spaces" (ACRL 2015, 8). Under this conceptualization, focus shifts away from the defined information literacy competencies and skills-based approach of the Standards to more flexible and practice-oriented frames, knowledge practices, and dispositions (Foasberg 2015). 
Informed by scholarship around threshold concepts (Meyer and Land 2006; Meyer, Land, and Baillie 2010), the Framework is organized into six frames, each anchored by a concept central to information literacy:

- Authority is Constructed and Contextual (AC)

- Information Creation as a Process (IC)

- Information Has Value (IV)

- Research as Inquiry (RI)

- Scholarship as Conversation (SC)

- Searching as Strategic Exploration (SE)

Each frame also consists of a set of knowledge practices, or "demonstrations of ways in which learners can increase their understanding of these information literacy concepts," and dispositions, which "describe ways in which to address the affective, attitudinal, or valuing dimension of learning" (ACRL 2015, 8). Rather than being considered prescriptive or exhaustive, the Framework is meant to offer librarians the flexibility to create information literacy learning outcomes and implementation strategies most appropriate for their institutional contexts, allowing for an ongoing process of design, development, and assessment of information literacy pedagogy (Foasberg 2015; Jacobson and Gibson 2015; Oakleaf 2014).

Since the adoption of the Framework, a number of studies have been published in which librarians have mapped its threshold concepts, knowledge practices, and dispositions to other relevant guiding documents as a means to inform and adapt information literacy pedagogy and to assess alignment between instructional approaches. For example, Willson and Angell (2017) mapped professional standards of the American Nurses Association onto related concepts in the Framework as part of the 
creation of an assessment rubric for student research papers. Burns, Gross, and Latham (2019) created crosswalks between the Framework and the domains and competencies of the American Association for School Libraries (AASL) National School Library Standards for Learners to assess alignment between instructional approaches in PK-12 and higher education settings. Dubicki (2019) performed a syllabus study at Monmouth University by mapping faculty-defined learning outcomes to the Framework to explore a tiered approach to information literacy instruction. In seeking to map the concepts of the Framework to the contents of other kinds of guiding documentation, the present study is broadly similar to those referenced above and numerous other examples across the library and information science literature, though it represents the first to focus on connections between the Framework and articulated GIS\&T learning objectives.

\section{Geographic Information Science and Technology Body of Knowledge}

The first edition of the Geographic Information Science and Technology Body of Knowledge (hereafter the BoK) was published in 2006 (DiBiase et al. 2006) as part of the Model Curricula initiative of the University Consortium for Geographic Information Science (UCGIS). The original BoK was conceived as the first edition of a dynamic work that would be updated and improved upon as the domain of GIS\&T continued to evolve. Much like the Framework, the BoK was not intended as a prescriptive or exhaustive document. Instead the authors put forth the "modest goal of helping bridge the gap between the GIS\&T higher education community and the practitioners, employers, and clients who populate the various GIS\&T professions" (DiBiase et al.

2006, 2). The BoK was organized hierarchically with 10 knowledge areas comprised of 73 units, which contained a total of 329 topics and 1,660 learning objectives. Included among the intended uses of the BoK were fundamental responsibilities commonly undertaken by geospatial educators and academic librarians alike, such as curriculum 
planning, program evaluation and assessment, and curriculum revision (ibid.).

A variety of studies related to these responsibilities have been conducted using the BoK (DiBiase et al. 2006) as a foundation for analysis. Prager and Plewe (2009) provide a detailed methodology for using the BoK as a tool for curriculum evaluation, assessing the similarities, differences, and alignments between desired course and curricular outcomes in introductory GIS courses at their respective institutions. DeMers (2009) compares the action verbs in the BoK learning objectives to those in Bloom's taxonomy (1956) to assess the extent to which the BoK objectives are geared towards learning across different cognitive domains. Prager (2012) discusses using the BoK as part of the integrated course design process (Fink 2003), offering valuable examples of how BoK learning objectives can be adapted for use in different educational contexts. More recently, Frazier, Wikle, and Kedron (2018) performed an in-depth comparison of the content of textbooks commonly used in introductory GIS courses, coding the content to match the original BoK units. The authors found disparities in the coverage of content from different BoK knowledge areas, with Analytical Methods and Geospatial Data receiving the most coverage and GIS\&T and Society receiving the least (ibid.).

In 2016, a primary goal of the BoK to be updated as a living document representing the GIS\&T domain began to be realized as the UCGIS published an online digital version, often referred to as the BoK 2.0 (Sinton 2017; UCGIS n.d.). The first online version (2016 Quarter 02) contained the same 329 topics as in the print edition of the BoK (DiBiase et al. 2006) and their associated learning objectives under the same 10 knowledge areas. Since then, a new editorial team has been working to add new topics, revise existing topics, restructure the knowledge areas, and expand content to include descriptive overviews of the topics, new and updated learning objectives, 
instructional assessment questions, and reference lists, all in a more easily searchable digital format (Sinton 2017). As quarterly updates are published, archival versions of existing and expanded topics are curated with permanent URLs, an important factor allowing for changes to the online version to be tracked over time and an asset when conducting studies like this one.

\section{Research Design}

\section{Materials}

At the time of this analysis, the most recent archival version of the BoK 2.0 published was 2019 Quarter 02 (UCGIS 2019). The 2019 Quarter 02 archival version contains a total of 290 topics and 1,556 learning objectives organized into 10 revised knowledge areas:

- Analytics and Modeling (AM)

- Computing Platforms (CP)

- Cartography and Visualization (CV)

- Domain Applications (DA)

- Data Capture (DC)

- Data Management (DM)

- Foundational Concepts (FC)

- GIS\&T and Society (GS)

- Knowledge Economy (KE)

- Programming and Development (PD)

The 2019 Quarter 02 archive is a mix of topics published in the original BoK containing only learning objectives (DiBiase et al. 2006), and topics created and/or expanded as 
part of the evolving BoK 2.0 digital edition containing learning objectives and newly developed content. For this project, only the learning objectives associated with each topic were included in the qualitative analysis. The number of learning objectives per topic ranged from one to fifteen, with a median of five. The following analysis was performed utilizing the BoK 2.0 2019 Quarter 02 archive (UCGIS 2019) and the Framework (ACRL 2015).

\section{Methods}

The complete web page for each BoK 2.0 2019 Quarter 02 topic was captured using the NCapture web browser extension and imported into NVivo 12 (QSR International 2018) as a PDF for qualitative analysis. The Framework effectively served as the data coding protocol for this study, with the six frames and their 83 associated knowledge practices and dispositions represented as unique codes in NVivo. For the purposes of coding, the same numbering scheme employed in the study by Burns, Gross, and Latham (2019) was adopted, in which each frame is assigned a Roman numeral based on alphabetical order (I. Authority is Constructed and Contextual, II. Information Creation as a Process, etc.). Knowledge practices are identified with the letter A and dispositions with the letter B, with the individual items under each numbered sequentially $(1,2,3$, etc.). Individual learning objectives were examined for each BoK 2.0 topic, and two rounds of coding were performed. In the first round of structural coding (Saldaña 2016), BoK 2.0 learning objectives were coded to one or more of the six frames based on their alignment to the concepts underlying each frame, as interpreted by the author from the narrative description of the frames and my own understanding of those concepts at the time of analysis. Structural coding serves "as a labeling and indexing device, allowing researchers to quickly access data likely to be relevant to a particular analysis from a larger data set" (Namey et al. 2008, 141). 
During the second round of analysis, the BoK 2.0 learning objectives coded to each frame in round one were subcoded to the more detailed knowledge practices and dispositions based on conceptual similarities, rendering the frames as "parent" codes and the knowledge practices and dispositions as their "children" (Saldaña 2016). An overarching goal of this coding process was the creation of a relative crosswalk, in which each knowledge practice and disposition in the Framework was mapped to at least one learning objective in the BoK 2.0 (Chan and Zeng 2006). Rather than establishing direct semantic equivalency between the elements of the Framework and the BoK 2.0, the crosswalk in this case is meant to identify a degree of conceptual similarity that highlights the potential for integrating information literacy and GIS\&T topics in the instructional design process (Table 1).

\section{[INSERT TABLE 1 HERE]}

Appendix 1 provides a more detailed look into the relative crosswalk process for the six frames, with 1-3 example learning objectives included for each of the knowledge practices and dispositions in the Framework. Readers are encouraged to review this appendix both as a reference to the methods employed in this study, and to see the wide array of BoK 2.0 topics that can be aligned in some way to the Framework. This appendix can be a useful starting point for considering how existing GIS\&T learning objectives could be adapted or built upon to more explicitly address desired information literacy learning goals.

\section{Results}

A total of 375 learning objectives from 182 topics were coded to one or more knowledge practices and dispositions at the end of the two rounds of qualitative analysis. Table 2 depicts the ratio of aligned BoK 2.0 topics (i.e., those with at least one learning objective coded to the Framework) to the total number of topics within each of 
the 10 knowledge areas. The three knowledge areas with the highest degree of alignment to the Framework based on this calculation are Domain Applications (DA), Cartography and Visualization (CV), and GIS\&T and Society (GS), while the Programming and Development (PD) knowledge area has the lowest alignment ratio. In all of the knowledge areas save for Data Management (DM) and Programming and Development, at least half of the topics could be aligned in some way to the knowledge practices and dispositions of the Framework.

\section{[INSERT TABLE 2 HERE]}

Table 3 shows a matrix of the alignments between the 10 knowledge areas and the six frames, with the numbers in each cell representing the number of learning objectives from each knowledge area coded to the different frames. Each learning objective is associated with only one knowledge area but may have been coded to more than one of the frames. While nearly all of the cells have at least one associated learning objective, this table can be used to quickly visualize intersections between the knowledge areas and the frames and to identify where such connections may offer the highest potential for integrating information literacy concepts into geospatial education.

\section{[INSERT TABLE 3 HERE]}

Appendix 2 provides additional details regarding the results of the qualitative analysis. The 182 topics with at least one learning objective aligned to the Framework are listed, and the frame(s) to which those learning objectives were coded are specified. While readers are encouraged to explore the BoK 2.0 for themselves, this appendix can serve as a quick reference to help librarians identify the topics that may be most relevant if they are seeking to design instructional content or engage in faculty collaborations to integrate particular information literacy concepts into the GIS\&T curriculum. 


\section{Discussion and Outlook}

\section{Examples of Conceptual Alignment}

There are learning objectives associated with a wide variety of BoK 2.0 topics that touch on the Framework's conceptualization of information literate learners as critical evaluators, consumers, and creators of information in a collaborative and continually changing information environment. For example, the Authority is Constructed and Contextual frame is focused on core concepts such as defining and evaluating types of authority and understanding the contexts in which information is produced and used. Connections to concepts in the BoK 2.0 may be apparent through learning goals associated with (1) evaluating the role of particular government agencies in the development of geospatial data, (2) assessing the source and appropriateness of a geospatial data set for a given mapping or spatial analysis task, and (3) recognizing the impact that web-based technologies have had on expanding the production of geographic information by both geospatial professionals and nonprofessionals. An example of an integrated learning objective for this frame could read: Evaluate the suitability of a given data set for a particular geospatial application, in terms of the properties of the data set (e.g., resolution, currency) and your confidence in its source.

The Information Creation as a Process frame emphasizes concepts such as the iterative nature of information creation and the unique capabilities and constraints of the resulting information products. Learners may explore these concepts through aligned topics in the BoK 2.0, including (1) the advantages and limitations of various geospatial technologies for analyzing and visualizing information, (2) the distortion patterns inherent in map projections and the effect that this choice can have on the interpretation and understanding of geographic information, and (3) the ways that data acquired from primary sources can influence, and differ from, that found in secondary sources. An 
example of a revised learning objective for this frame could read: Describe a use case where the creation of an interactive web map would be the preferred format for conveying information to your audience.

The Information Has Value frame is focused on the various dimensions of value characteristic of information, as they relate to rights and responsibilities, access and sharing practices, and impactful uses in scholarly and other contexts. Alignment with BoK 2.0 topics may be evident when learners consider (1) ideas about how perspectives around the production of, and access to, geospatial data may differ between the data creators and a variety of prospective users, (2) issues around copyright and open access in relation to the use of geospatial content created by others, along with their own rights as creators of maps and other outputs, (3) ways that metadata increases the value of, and enables use of, geospatial data, and (4) privacy implications of using geographic information derived from activities like location tracking, crowdsourcing, and social media, and sharing such information themselves. An example of an enhanced learning objective for this frame could read: For a series of three open geospatial data sets provided to you, list the questions you would want answered before using them based on the metadata (or lack of metadata) included with each.

The Research as Inquiry frame examines the iterative process of identifying and addressing gaps in disciplinary knowledge and the range of investigative methods that may be employed in research. Drawing on the BoK 2.0, these concepts may be apparent when learners are tasked with (1) articulating research questions with a geospatial component that may be of interest to scholars in their own discipline and across other domains, (2) appreciating the potential ethical challenges associated with a given use of geospatial information and posing multiple possible solutions, and (3) determining the scope of a project in the context of geospatial data needs, analysis workflows, and 
output required. An example of a revised learning objective for this frame could read: Discuss at least two ways that a geospatial approach can be utilized to address research questions in a current area of interest within your discipline.

The Scholarship as Conversation frame considers ideas around the discursive practices of scholarly communities, the diversity of perspectives, and the advancement of knowledge over time. Connections to concepts in the BoK 2.0 may be evident as learners are asked to (1) critically examine maps made through different approaches or presented through different media to inform the creation of their own geographic information products, (2) identify relevant conferences or other venues through which they can participate in the exchange of geospatial knowledge, (3) differentiate between how they might communicate the design, methods, and results of a project to GIS and non-GIS audiences, and (4) evaluate notable critiques in the history of the GIS\&T domain, responses to those critiques, and how such discussions influenced the further development of the field. An example of an adapted learning objective for this frame could read: Prepare two maps using the same data set, one formatted for a conference poster presented to a scholarly audience and another formatted as a web map for the general public.

Finally, the Searching as Strategic Exploration frame is focused on the process of finding, accessing, and evaluating information sources and their applicability for a given information need. Alignments with concepts in the BoK 2.0 may be apparent through learning objectives such as (1) describing and accessing the leading academic journals and trade publications serving the GIS\&T community, (2) creating a bibliography of scholarly and professional articles relevant to a specific GIS\&T project, (3) locating historical maps in both print and digital formats and preparing them for georeferencing, and (4) identifying, acquiring, and preparing data from multiple sources 
to carry out a spatial analysis project. An example of an integrated learning objective for this frame could read: For your chosen research topic, retrieve relevant articles from at least one academic journal and one trade publication serving the GIS\&T community. The connections described above are just some of those uncovered through an examination of the alignment between the Framework and the BoK 2.0, and they offer opportunities for librarians to purposefully integrate information literacy instruction into geospatial education in the GIS\&T curriculum and across other disciplinary contexts.

\section{Opportunities for Curricular Engagement}

In relation to the GIS\&T curriculum, it is interesting to note that in this study, topics in the BoK 2.0 knowledge area of GIS\&T and Society (GS) ranked third highest in terms of alignment ratio with the Framework (see Table 2), while Frazier, Wikle, and Kedron (2018) found in their study of common introductory GIS\&T textbooks that it was the knowledge area to receive the least amount of coverage. The GIS\&T and Society knowledge area covers broad topics including the evolving landscape of geospatial technologies, participatory practices in GIS\&T, and how political, economic, legal, and

cultural factors influence access to, and use of, geospatial technologies. Approaching these topics through an information literacy lens can offer both librarians and disciplinary faculty an avenue for addressing important topics that may otherwise be underrepresented in introductory GIS\&T courses.

The value of metadata is another important but underrepresented topic that could benefit from an integration with information literacy concepts and faculty/librarian collaborations, especially in today's dynamic information landscape where myriad sources of geospatial data are seemingly accessible with the push of a button, and with many of today's GIS\&T students becoming geospatial data creators themselves. In an analysis of nearly 1,700 GIS course syllabi from 126 research universities, Kedron et al. 
(2016) found that less than 5\% of all courses, ranging from the introductory undergraduate level to the advanced graduate level, indicated coverage of metadata standards and infrastructure, making it the lowest or second lowest ranking topic covered (out of 17) across each instructional level. Learning objectives related to the importance of geospatial metadata are represented across multiple topics and knowledge areas in the BoK 2.0 and align with multiple concepts in the Framework.

In regards to other disciplinary contexts, the Domain Applications (DA) knowledge area, which addresses links between foundational GIS\&T concepts and their potential impacts across a broad range of application areas, ranked first in terms of alignment ratio with the Framework. Many of the BoK 2.0 learning objectives noted above and detailed further in Appendix 1 may be fundamental, though not necessarily unique, to the GIS\&T domain and could be adapted to integrate relevant information literacy and geospatial concepts into instruction in other disciplines. For this reason, subject librarians working with faculty and students across various disciplines may also be able to use maps and geographic information as a lens through which the information literacy concepts of the Framework can be addressed in their respective knowledge areas, and may find willing and able collaborators in their map and geospatial librarian colleagues (and vice versa). Indeed, the development of services for, and outreach to, potential GIS users outside of the traditional GIS\&T disciplines is an area of ongoing interest among geospatial librarians (Fish and Piekielek 2016; Kong, Fosmire, and Branch 2017).

\section{Considerations for Integrated Instruction}

There are several key concepts related to information literacy instruction that served as inspiration for the present study, and that are worth briefly discussing in the context of its results. First, the wide variety of BoK 2.0 topics and learning objectives with some 
degree of alignment to the Framework illustrates the potential for integrating information literacy into GIS\&T instruction in a way that connects these core concepts to topics where students may have previous knowledge and be personally invested, increasing the chances for knowledge transfer and retention (Kuglitsch 2015). Second, all of the core concepts underlying the Framework cannot be, and are not meant to be, taught during a single information literacy session in a student's academic career (ACRL 2015). The alignments between the Framework and BoK 2.0 noted in this study, and particularly the connections between the frames and a range of foundational and more advanced geospatial topics likely to be encountered at different stages of a student's career, will hopefully be of use to librarians engaging in curriculum mapping efforts and seeking opportunities to integrate the frames at appropriate times and in appropriate venues to benefit their students (and see Appendix 2).

Finally, a notable challenge in GIS instruction is striking the right balance between time spent on hands-on skills training and time spent on teaching conceptual foundations (Powell and Kong 2017), especially in the short time frames often characteristic of library-based instruction (Gross, Latham, and Julien 2018). Because of this, there can sometimes be a tendency towards emphasizing "buttonology" (i.e., introductory training focused on the interface and use of particular software programs) or utilizing a "cookbook" method (i.e., following step-by-step instructions to complete particular tasks without requiring a deeper understanding), approaches discussed, and cautioned against, in both the library and information science (Jablonski 2004; Russell and Hensley 2017) and geospatial education literature (Bearman et al. 2016; Kedron et al. 2016). The connections between information literacy and geospatial education highlighted through this study will hopefully aid instructors in resisting this tendency 
and provide support for building learning opportunities that pair relevant information literacy concepts with the acquisition and application of GIS\&T skills.

\section{Limitations of the Study}

Although the qualitative analysis methods used in this study may be replicated, it is important to note that the resulting crosswalks relating the Framework and BoK 2.0 reflect the author's interpretations of the concepts articulated in both documents and are likely not directly reproducible (see Appendix 1). Others undertaking a similar analysis of these documents may see connections I have missed or question connections I have made based on their own interpretations of these concepts. For that reason, the results of this study are not meant to be prescriptive or exhaustive, but to encourage further exploration of the connections between the Framework and BoK 2.0 in ways that best suit the instructional design needs of those with responsibilities related to information literacy and/or geospatial education. Furthermore, the BoK 2.0 is updated quarterly, and new or expanded topics with additional connections to the Framework are likely to be published over time.

While an overarching goal at the outset of the qualitative analysis was the creation of a relative crosswalk (Chan and Zeng 2006) between the knowledge practices and dispositions of the Framework and the learning objectives of the BoK 2.0 based on conceptual similarity, the results may be better characterized as a many-to-many relationship between the documents. In this case, individual knowledge practices and dispositions in the Framework could be connected to many BoK 2.0 learning objectives, while the same BoK 2.0 learning objective could also be connected to multiple knowledge practices and dispositions. In addition, nine of the 83 knowledge practices and dispositions considered were not directly associated with any BoK 2.0 learning 
objectives, with these particular knowledge practices and dispositions being less specific than others in the Framework (see Appendix 1).

\section{What Comes Next}

The results of the present study highlight the connections between information literacy concepts in the Framework and many GIS\&T topics and learning objectives in the BoK 2.0. Rather than preclude further analysis, these results are meant to encourage exploration of how the connections may be best addressed in local institutional contexts, through efforts such as curriculum mapping and instructional design, with the hope that these efforts will be shared out to the wider community of map, geospatial, and subject librarians, and the disciplinary faculty with whom we may collaborate. An analogy may be drawn to the early steps of Oakleaf's (2014) roadmap, where these results may serve as inspiration and call attention to adaptable learning outcomes, but where much of the hard but rewarding work of identifying potential collaborations and designing, implementing, assessing, and sharing instructional content is yet to be done.

At the time of writing, the ACRL Framework for Information Literacy Sandbox (hereafter the Sandbox, ACRL n.d.) contains approximately 200 shared resources to aid librarians in implementing the Framework in their instructional practices. However, there are no resources related to geospatial education in the Sandbox, and Geography is currently absent from the list of disciplines to be browsed for content. The same is true for a variety of other recently published volumes focused on disciplinary applications of the Framework and providing lesson plans for librarians (Bravender, McClure, and Schaub 2015; Burkhardt 2016; Godbey, Wainscott, and Goodman 2017), with the notable absence of any content associated with GIS\&T topics. The results of this study demonstrate that the integration of information literacy concepts into geospatial education can be a fruitful line of inquiry, and one in need of further consideration and 
resource sharing to address such absences. There is much potential for map and geospatial librarians to draw on the knowledge of, and contribute back to, active scholarly communities in the areas of information literacy instruction, GIS\&T pedagogy, and the scholarship of teaching and learning, with significant benefits for our students, faculty collaborators, and librarian colleagues alike.

Acknowledgements

I wish to thank the University Consortium for Geographic Information Science and Diana Sinton, in particular, for granting permission to capture and store the complete web pages for the BoK 2.0 to facilitate qualitative analysis. Thanks also to Diana for taking the time to provide me with additional context regarding the development of the BoK and the process for ongoing revisions to the BoK 2.0. Thanks to Sharon Sadvari and Meris Longmeier for their feedback on an early draft of this paper, and to the two anonymous reviewers whose valuable suggestions have improved the quality of this manuscript. 


\section{References}

ACRL. n.d. ACRL framework for information literacy sandbox. Accessed August 25, 2019. https://sandbox.acrl.org/.

ACRL. 2000. Information literacy competency standards for higher education. Accessed June 5, 2019. https://alair.ala.org/handle/11213/7668.

ACRL. 2015. Framework for information literacy for higher education. Accessed June 5, 2019. http://www.ala.org/acrl/files/issues/infolit/framework.pdf.

Battersby, S. 2017. Map projections. In The geographic information science \& technology body of knowledge, ed. J. P. Wilson, 2nd quarter 2017 edition. doi: 10.22224/gistbok/2017.2.7.

Bearman, N., N. Jones, I. André, H. A. Cachinho, and M. DeMers. 2016. The future role of GIS education in creating critical spatial thinkers. Journal of geography in higher education 40(3): 394-408. doi: 10.1080/03098265.2016.1144729.

Bloom, B. S., ed. 1956. Taxonomy of educational objectives: The classification of educational goals. Handbook 1: Cognitive domain. New York: Longmans, Green \& Co.

Bolstad, P. 2018. GIS\&T and forestry. In The geographic information science \& technology body of knowledge, ed. J. P. Wilson, 1st quarter 2018 edition. doi: 10.22224/gistbok/2018.1.6.

Bravender, P., H. McClure, and G. Schaub, eds. 2015. Teaching information literacy threshold concepts: Lesson plans for librarians. Chicago: Association of College and Research Libraries.

Burkhardt, J. M. 2016. Teaching information literacy reframed: 50+ framework-based exercises for creating information-literate learners. Chicago: ALA NealSchuman.

Burns, E., M. Gross, and D. Latham. 2019. The information literacy continuum: Mapping the ACRL framework to the AASL school library standards. School libraries worldwide 25(1): 1-20. doi: 10.14265.25.1.001.

Castagneri, J. 2019. United States census data. In The geographic information science \& technology body of knowledge, ed. J. P. Wilson, 1st quarter 2019 edition. doi: 10.22224/gistbok/2019.1.8. 
Chan, L. M., and M. L. Zeng. 2006. Metadata interoperability and standardization - a study of methodology part I: Achieving interoperability at the schema level. $D$ Lib magazine 12(6). Online publication. doi: 10.1045/june2006-chan.

Clarke, K. 2017. Cellular automata. In The geographic information science \& technology body of knowledge, ed. J. P. Wilson, 3rd quarter 2017 edition. doi: 10.22224/gistbok/2017.3.9.

Çöltekin, A., H. Janetzko, and S. I. Fabrikant. 2018. Geovisualization. In The geographic information science \& technology body of knowledge, ed. J. P. Wilson, 2nd quarter 2018 edition. doi: 10.22224/gistbok/2018.2.6.

DeMers, M. N. 2009. Using intended learning objectives to assess curriculum materials: The UCGIS body of knowledge. Journal of geography in higher education 33(sup1): S70-S77. doi: 10.1080/03098260903033980.

DiBiase, D. 1996. Rethinking laboratory education for an introductory course on geographic information. Cartographica 33(4): 61-72.

DiBiase, D. 2017. Professional and practical ethics of GIS\&T. In The geographic information science \& technology body of knowledge, ed. J. P. Wilson, 2nd quarter 2017 edition. doi: 10.22224/gistbok/2017.2.2.

DiBiase, D. 2018. Competence in GIS\&T knowledge work. In The geographic information science \& technology body of knowledge, ed. J. P. Wilson, 3rd quarter 2018 edition. doi: 10.22224/gistbok/2018.3.10.

DiBiase, D., M. N. DeMers, A. Johnson, K. Kemp, A. T. Luck, B. Plewe, and E. Wentz. 2006. Geographic information science \& technology body of knowledge. Washington, D.C.: Association of American Geographers and University Consortium for Geographic Information Science.

Dodsworth, E., and L. Laliberté. 2016. Teaching spatial literacy: Location, distance, and scale. In The new information literacy instruction, ed. P. Ragains and M. S. Wood, 173-188. Lanham, MD: Rowman \& Littlefield.

Dubicki, E. 2019. Mapping curriculum learning outcomes to ACRL's framework threshold concepts: A syllabus study. The journal of academic librarianship 45(3): 288-298. doi: 10.1016/j.acalib.2019.04.003.

Field, K. 2017. Cartograms. In The geographic information science \& technology body of knowledge, ed. J. P. Wilson, 3rd quarter 2017 edition. doi: 10.22224/gistbok/2017.3.8. 
Fink, L. D. 2003. Creating significant learning experiences: An integrated approach to designing college courses. San Francisco: Jossey-Bass.

Fish, C. 2018. Spatiotemporal representation. In The geographic information science \& technology body of knowledge, ed. J. P. Wilson, 4th quarter 2018 edition. doi: 10.22224/gistbok/2018.4.6.

Fish, C. S., and N. B. Piekielek. 2016. Targeting disciplines for GIS outreach using bibliometric analysis. Journal of map \& geography libraries 12(3): 258-280. doi: $10.1080 / 15420353.2016 .1221870$.

Foasberg, N. M. 2015. From standards to frameworks for IL: How the ACRL framework addresses critiques of the standards. portal: Libraries and the academy 15(4): 699-717. doi: 10.1353/pla.2015.0045.

Frazier, A. E., T. Wikle, and P. Kedron. 2018. Exploring the anatomy of geographic information systems and technology (GIS\&T) textbooks. Transactions in GIS 22(1): 165-182. doi: 10.1111/tgis.12301.

Giordano, A. 2019. GIS\&T and the digital humanities. In The geographic information science \& technology body of knowledge, ed. J. P. Wilson, 2nd quarter 2019 edition. doi: 10.22224/gistbok/2019.2.8.

Godbey, S., S. B. Wainscott, and X. Goodman, eds. 2017. Disciplinary applications of information literacy threshold concepts. Chicago: Association of College and Research Libraries.

Goodspeed, R., and J. Grengs. 2017. GIS\&T in urban and regional planning. In The geographic information science \& technology body of knowledge, ed. J. P. Wilson, 4th quarter 2017 edition. doi: 10.22224/gistbok/2017.4.2.

Griffith, D. 2017. Spatial autocorrelation. In The geographic information science \& technology body of knowledge, ed. J. P. Wilson, 4th quarter 2017 edition. doi: 10.22224/gistbok/2017.4.13.

Gross, M., D. Latham, and H. Julien. 2018. What the framework means to me: Attitudes of academic librarians toward the ACRL framework for information literacy for higher education. Library \& information science research 40(3-4): 262-268. doi: 10.1016/j.lisr.2018.09.008.

Hamerlinck, J. D. 2015. Whither goes the "maps" course? Maintaining map-use concepts, skills, and appreciation in GIS\&T curricula. Cartography and geographic information science 42(sup1): 11-17. doi: 10.1080/15230406.2015.1059140. 
Holstein, A. L. 2015. Geographic information and technologies in academic libraries: An ARL survey of services and support. Information technology and libraries 34(1): 38-51. doi: 10.6017/ital.v34i1.5699.

Hu, Y., and W. Li. 2017. Spatial data infrastructures. In The geographic information science \& technology body of knowledge, ed. J. P. Wilson, 2nd quarter 2017 edition. doi: 10.22224/gistbok/2017.2.1.

Huang, Q. 2018. Social media analytics. In The geographic information science \& technology body of knowledge, ed. J. P. Wilson, 1st quarter 2018 edition. doi: 10.22224/gistbok/2018.1.10.

Jablonski, J. 2004. Information literacy for GIS curricula: An instructional model for faculty. Journal of map \& geography libraries 1(1): 41-58. doi: 10.1300/J230v01n01_03.

Jacobson, T. E., and C. Gibson. 2015. First thoughts on implementing the framework for information literacy. Communications in information literacy 9(2): 102-110.

Kedron, P., A. Frazier, C. Greene, and D. Mitchell. 2016. Curriculum design for upperand advanced-level GIS classes: Are new skills being taught and integrated? GI_Forum 4(1): 324-335. doi: 10.1553/giscience2016_01_s324.

Kerski, J. 2016. Location privacy. In The geographic information science \& technology body of knowledge, ed. J. P. Wilson, 3rd quarter 2016 edition. doi: 10.22224/gistbok/2016.3.2.

Kimsey, M. B., and S. L. Cameron. 2005. Teaching and assessing information literacy in a geography program. Journal of geography 104(1): 17-23. doi: $10.1080 / 00221340508978918$.

Kinkeldey, C., and H. Senaratne. 2018. Representing uncertainty. In The geographic information science \& technology body of knowledge, ed. J. P. Wilson, 2nd quarter 2018 edition. doi: 10.22224/gistbok/2018.2.3.

Kong, N., M. Fosmire, and B. D. Branch. 2017. Developing library GIS services for humanities and social science: An action research approach. College \& research libraries 78(4): 413-427. doi: 10.5860/crl.78.4.413.

Kong, N. N., C. Bynum, C. Johnson, J. Sdunzik, and X. Qin. 2017. Spatial information literacy for digital humanities: The case study of leveraging geospatial information for African American history education. College \& undergraduate libraries 24(2-4): 376-392. doi: 10.1080/10691316.2017.1329044. 
Krygier, J., and D. C. Peoples. 2003. Geographic information literacy and the world wide web. In Maps and the internet, ed. M. P. Peterson, 17-33. Oxford, UK: Elsevier Science Ltd.

Kuglitsch, R. Z. 2015. Teaching for transfer: Reconciling the framework with disciplinary information literacy. portal: Libraries and the academy 15(3): 457470. doi: 10.1353/pla.2015.0040.

LaLonde, T., and N. Piekielek. 2018. Planning for change: A maps and geospatial information services survey. Issues in science \& technology librarianship 90(Summer). Online publication. doi: 10.5062/f43f4mw4.

Lam, N. 2019. Resolution. In The geographic information science \& technology body of knowledge, ed. J.P. Wilson, 2nd quarter 2019 edition. doi: 10.22224/gistbok/2019.2.11.

Laube, P. 2017. Computational movement analysis. In The geographic information science \& technology body of knowledge, ed. J. P. Wilson, 2nd quarter 2017 edition. doi: 10.22224/gistbok/2017.2.6.

Le Noc, M. 2019. Feminist critiques of GIS. In The geographic information science \& technology body of knowledge, ed. J. P. Wilson, 2nd quarter 2019 edition. doi: 10.22224/gistbok/2019.2.12.

Leszczynski, A. 2017. Epistemological critiques. In The geographic information science \& technology body of knowledge, ed. J. P. Wilson, 4th quarter 2017 edition. doi: 10.22224/gistbok/2017.4.1.

March, G. 2011. Surveying campus GIS and GPS users to determine role and level of library services. Journal of map \& geography libraries 7(2): 154-183. doi: 10.1080/15420353.2011.566838.

March, G., and E. Scarletto. 2017. The evolution of GIS services within North American academic libraries: Documenting change through the decades (19952016). Journal of map \& geography libraries 13(2): 222-245. doi: 10.1080/15420353.2017.1313803.

Mathews, A. J., and A. E. Frazier. 2017. Unmanned aerial systems. In The geographic information science \& technology body of knowledge, ed. J. P. Wilson, 2nd quarter 2017 edition. doi: 10.22224/gistbok/2017.2.4.

Meyer, J. H. F., and R. Land, eds. 2006. Overcoming barriers to student understanding: Threshold concepts and troublesome knowledge. London: Routledge. 
Meyer, J. H. F., R. Land, and C. Baillie, eds. 2010. Threshold concepts and transformational learning. Rotterdam, Netherlands: Sense Publishers.

Miller, F. 2018. GIS\&T and marketing. In The geographic information science \& technology body of knowledge, ed. J. P. Wilson, 2nd quarter 2018 edition. doi: 10.22224/gistbok/2018.2.2.

Moreno-Sanchez, R. 2018. Openness. In The geographic information science \& technology body of knowledge, ed. J. P. Wilson, 1st quarter 2018 edition. doi: 10.22224/gistbok/2018.1.5.

Morgan, J. D., and J. Evans. 2018. Aggregation of spatial entities and legislative redistricting. In The geographic information science \& technology body of knowledge, ed. J. P. Wilson, 3rd quarter 2018 edition. doi: 10.22224/gistbok/2018.3.6.

Mu, L., and S. Holloway. 2019. Neighborhoods. In The geographic information science \& technology body of knowledge, ed. J. P. Wilson, 1st quarter 2019 edition. doi: 10.22224/gistbok/2019.1.11.

Namey, E., G. Guest, L. Thairu, and L. Johnson. 2008. Data reduction techniques for large qualitative data sets. In Handbook for team-based qualitative research, ed. G. Guest and K. M. MacQueen, 137-161. Lanham, MD: AltaMira Press.

Nazari, M. 2011. A contextual model of information literacy. Journal of information science 37(4): 345-359. doi: 10.1177/0165551511403544.

Nazari, M. 2016. The actuality of determining information need in geographic information systems and science (GIS): A context-to-concept approach. Library \& information science research 38(2): 133-147. doi: 10.1016/j.lisr.2016.04.005.

Oakleaf, M. 2014. A roadmap for assessing student learning using the new framework for information literacy for higher education. The journal of academic librarianship 40(5): 510-514. doi: 10.1016/j.acalib.2014.08.001.

Ooms, K., and A. Skarlatidou. 2018. Usability engineering and evaluation. In The geographic information science \& technology body of knowledge, ed. J. P. Wilson, 1st quarter 2018 edition. doi: 10.22224/gistbok/2018.1.9.

Piovan, S. 2019. Historical maps in GIS. In The geographic information science \& technology body of knowledge, ed. J. P. Wilson, 1st quarter 2019 edition. doi: 10.22224/gistbok/2019.1.4. 
Poorthuis, A. 2018. Big data visualization. In The geographic information science \& technology body of knowledge, ed. J. P. Wilson, 3rd quarter 2018 edition. doi: 10.22224/gistbok/2018.3.5.

Powell, S., and N. N. Kong. 2017. Beyond the one-shot: Intensive workshops as a platform for engaging the library in digital humanities. College $\&$ undergraduate libraries 24(2-4): 516-531. doi: 10.1080/10691316.2017.1336955.

Prager, S. D. 2012. Using the GIS\&T body of knowledge for curriculum design: Different design for different contexts. In Teaching geographic information science and technology in higher education, ed. D. J. Unwin, K. E. Foote, N. J. Tate, and D. DiBiase, 63-80. Chichester, UK: Wiley-Blackwell.

Prager, S. D., and B. Plewe. 2009. Assessment and evaluation of GIScience curriculum using the geographic information science and technology body of knowledge. Journal of geography in higher education 33(sup1): S46-S69. doi: 10.1080/03098260903034012.

QSR International. 2018. NVivo qualitative data analysis software (version 12).

Quinn, S. 2018. Web GIS. In The geographic information science \& technology body of knowledge, ed. J. P. Wilson, 1st quarter 2018 edition. doi: 10.22224/gistbok/2018.1.11.

Ricker, B., and R. E. Roth. 2018. Mobile maps and responsive design. In The geographic information science \& technology body of knowledge, ed. J. P. Wilson, 2nd quarter 2018 edition. doi: 10.22224/gistbok/2018.2.5.

Rickles, P., M. Haklay, C. Ellul, and A. Skarlatidou. 2017. Citizen science with GIS\&T. In The geographic information science \& technology body of knowledge, ed. J. P. Wilson, 3rd quarter 2017 edition. doi: 10.22224/gistbok/2017.3.5.

Rinner, C. 2018. Spatial decision support. In The geographic information science \& technology body of knowledge, ed. J. P. Wilson, 2nd quarter 2018 edition. doi: 10.22224/gistbok/2018.2.1.

Robinson, A. 2017. Geovisual analytics. In The geographic information science \& technology body of knowledge, ed. J. P. Wilson, 3rd quarter 2017 edition. doi: 10.22224/gistbok/2017.3.6.

Ruddell, D., and K. Foster. 2018. GIS\&T and geodesign. In The geographic information science \& technology body of knowledge, ed. J. P. Wilson, 3rd quarter 2018 edition. doi: 10.22224/gistbok/2018.3.3. 
Russell, J. E., and M. K. Hensley. 2017. Beyond buttonology: Digital humanities, digital pedagogy, and the ACRL framework. College \& research libraries news 78(11): 588-591. doi: 10.5860/crln.78.11.588.

Saldaña, J. 2016. The coding manual for qualitative researchers. 3rd edition. Los Angeles: SAGE.

Scarletto, E. 2013. Data driven program planning for GIS instruction. Issues in science and technology librarianship 73(Summer). Online publication. doi: 10.5062/f4r49nrf.

Sinton, D. S. 2017. The GIS\&T BoK: Where is it now, and where will you take it tomorrow? Accessed July 7, 2019. https://www.directionsmag.com/article/1066.

Tait, A. 2018. Visual hierarchy and layout. In The geographic information science \& technology body of knowledge, ed. J. P. Wilson, 2nd quarter 2018 edition. doi: 10.22224/gistbok/2018.2.4.

Thatcher, J. 2018. Cartography and power. In The geographic information science \& technology body of knowledge, ed. J. P. Wilson, 1st quarter 2018 edition. doi: 10.22224/gistbok/2018.1.7.

UCGIS. n.d. GIS\&T body of knowledge. Accessed June 5, 2019. https://gistbok.ucgis.org/.

UCGIS. 2019. GIS\&T body of knowledge: 2019 quarter 02. Accessed July 5, 2019. https://gistbok.ucgis.org/archives/2019-quarter-02.

Usery, E. L. 2019. Problems of large spatial databases. In The geographic information science \& technology body of knowledge, ed. J. P. Wilson, 2nd quarter 2019 edition. doi: 10.22224/gistbok/2019.2.13.

White, T. 2017. Symbolization and the visual variables. In The geographic information science \& technology body of knowledge, ed. J. P. Wilson, 2nd quarter 2017 edition. doi: 10.22224/gistbok/2017.2.3.

Willson, G., and K. Angell. 2017. Mapping the Association of College and Research Libraries information literacy framework and nursing professional standards onto an assessment rubric. Journal of the medical library association 105(2): 150-154. doi: 10.5195/JMLA.2017.39.

Wright, D. J. 2017. GIS\&T and marine science. In The geographic information science \& technology body of knowledge, ed. J. P. Wilson, 3rd quarter 2017 edition. doi: 10.22224/gistbok/2017.3.3. 
Appendix 1. Crosswalks between ACRL Framework knowledge practices and dispositions and GIS\&T Body of Knowledge learning objectives.

Note: In-text citations provided for specific GIS\&T Body of Knowledge learning objectives indicate that they derive from new or expanded topics in the digital edition and credit the appropriate BoK 2.0 authors. All other learning objectives derive from topics that have not been substantially revised from the first edition of the BoK and are attributed to DiBiase et al. (2006).

\section{Authority is Constructed and Contextual}

\begin{tabular}{|c|c|}
\hline ACRL Framework & GIS\&T Body of Knowledge \\
\hline $\begin{array}{l}\text { A. Knowledge Practices } \\
\text { Learners who are developing their } \\
\text { information literate abilities }\end{array}$ & \\
\hline \multirow[t]{2}{*}{$\begin{array}{l}\text { 1. define different types of authority, such } \\
\text { as subject expertise (e.g., scholarship), } \\
\text { societal position (e.g., public office or } \\
\text { title), or special experience (e.g., } \\
\text { participating in a historic event) }\end{array}$} & $\begin{array}{l}\text { DC-22: Discuss the mission, history, constituencies, and } \\
\text { activities of governmental entities such as the Bureau of } \\
\text { Land Management (BLM), United States Geological } \\
\text { Survey (USGS) and the Environmental Protection Agency } \\
\text { (EPA) as they relate to support of professionals and } \\
\text { organizations involved in GIS\&T. }\end{array}$ \\
\hline & $\begin{array}{l}\text { FC-06: Evaluate the differences in how various parties } \\
\text { think or feel differently about a place being modeled. }\end{array}$ \\
\hline \multirow{2}{*}{$\begin{array}{l}\text { 2. use research tools and indicators of } \\
\text { authority to determine the credibility of } \\
\text { sources, understanding the elements that } \\
\text { might temper this credibility }\end{array}$} & $\begin{array}{l}\text { DA-33: Describe traditional and big data sources of } \\
\text { spatial information about cities, and describe their } \\
\text { strengths and weaknesses. (Goodspeed and Grengs 2017) }\end{array}$ \\
\hline & $\begin{array}{l}\text { FC-28: Explain the distinction between primary and } \\
\text { secondary data sources in terms of census data, } \\
\text { cartographic data, and remotely sensed data. }\end{array}$ \\
\hline \multirow{2}{*}{$\begin{array}{l}\text { 3. understand that many disciplines have } \\
\text { acknowledged authorities in the sense of } \\
\text { well-known scholars and publications that } \\
\text { are widely considered "standard," and } \\
\text { yet, even in those situations, some } \\
\text { scholars would challenge the authority of } \\
\text { those sources }\end{array}$} & $\begin{array}{l}\text { FC-29: Discuss the role of the U.S. Census Bureau in } \\
\text { contributing to the development of the U.S. geospatial } \\
\text { industry. }\end{array}$ \\
\hline & $\begin{array}{l}\text { GS-15: Discuss the potential role of agency (individual } \\
\text { action) in resisting dominant practices and in using } \\
\text { GIS\&T in ways that are consistent with feminist } \\
\text { epistemologies and politics. (Le Noc 2019) }\end{array}$ \\
\hline \multirow{2}{*}{$\begin{array}{l}\text { 4. recognize that authoritative content } \\
\text { may be packaged formally or informally } \\
\text { and may include sources of all media } \\
\text { types }\end{array}$} & $\begin{array}{l}\text { AM-40: Explain how a leading World Wide Web-based } \\
\text { routing system works (e.g., MapQuest, Yahoo Maps, } \\
\text { Google). }\end{array}$ \\
\hline & $\begin{array}{l}\text { CV-03: Assess the data quality of a source dataset for } \\
\text { appropriateness for a given mapping task, including an } \\
\text { evaluation of the data resolution, extent, currency or date } \\
\text { of compilation, and level of generalization in the attribute } \\
\text { classification. }\end{array}$ \\
\hline \multirow{2}{*}{$\begin{array}{l}\text { 5. acknowledge they are developing their } \\
\text { own authoritative voices in a particular } \\
\text { area and recognize the responsibilities } \\
\text { this entails, including seeking accuracy } \\
\text { and reliability, respecting intellectual } \\
\text { property, and participating in } \\
\text { communities of practice }\end{array}$} & $\begin{array}{l}\text { DC-28: Explain why making comparisons of Census data } \\
\text { across geographies or across time can be problematic. } \\
\text { (Castagneri 2019) }\end{array}$ \\
\hline & $\begin{array}{l}\text { KE-32: Self-assess your competencies relative to the } \\
\text { Geospatial Technology Competency Model. (DiBiase } \\
\text { 2018) }\end{array}$ \\
\hline
\end{tabular}




\begin{tabular}{|l|l|}
\hline $\begin{array}{l}\text { 6. understand the increasingly social } \\
\text { nature of the information ecosystem } \\
\text { where authorities actively connect with } \\
\text { one another and sources develop over } \\
\text { time }\end{array}$ & $\begin{array}{l}\text { CV-26: Describe how all maps are produced within } \\
\text { relations of power and knowledge. Describe how all maps } \\
\text { also express specific relations of power and knowledge. } \\
\text { (Thatcher 2018) }\end{array}$ \\
\cline { 2 - 2 } & $\begin{array}{l}\text { GS-17: Evaluate the impact of geospatial technologies } \\
\text { (e.g., Google Earth) that allow nongeospatial } \\
\text { professionals to create, distribute, and map geographic } \\
\text { information. }\end{array}$ \\
\hline $\begin{array}{l}\text { B. Dispositions } \\
\text { Learners who are developing their } \\
\text { information literate abilities }\end{array}$ & \\
\hline $\begin{array}{l}\text { 1. develop and maintain an open mind } \\
\text { when encountering varied and sometimes } \\
\text { conflicting perspectives }\end{array}$ & $\begin{array}{l}\text { FC-20: Construct two maps about a conflict or war } \\
\text { producing one supportive of each side's viewpoint. }\end{array}$ \\
\hline $\begin{array}{l}\text { 2. motivate themselves to find } \\
\text { authoritative sources, recognizing that } \\
\text { authority may be conferred or manifested } \\
\text { in unexpected ways }\end{array}$ & PD-05: Acquire data from primary and secondary sources. \\
\hline $\begin{array}{l}\text { 3. develop awareness of the importance } \\
\text { of assessing content with a skeptical } \\
\text { stance and with a self-awareness of their } \\
\text { own biases and worldview }\end{array}$ & $\begin{array}{l}\text { GS-18: Recognize the impact of one's social background } \\
\text { on one's own geographic worldview and perceptions and } \\
\text { how it influences one's use of GIS. }\end{array}$ \\
\hline $\begin{array}{l}\text { 4. question traditional notions of granting } \\
\text { authority and recognize the value of } \\
\text { diverse ideas and worldviews }\end{array}$ & $\begin{array}{l}\text { GS-20: Demonstrate how changing the geometry of } \\
\text { regions changes the data values (e.g., voting patterns } \\
\text { before and after redistricting). (Morgan and Evans 2018) }\end{array}$ \\
\hline $\begin{array}{l}\text { 5. are conscious that maintaining these } \\
\text { attitudes and actions requires frequent } \\
\text { self-evaluation }\end{array}$ & \\
\hline
\end{tabular}

\section{Information Creation as a Process}

\begin{tabular}{|c|c|}
\hline ACRL Framework & GIS\&T Body of Knowledge \\
\hline \multicolumn{2}{|l|}{$\begin{array}{l}\text { A. Knowledge Practices } \\
\text { Learners who are developing their } \\
\text { information literate abilities }\end{array}$} \\
\hline \multirow{3}{*}{$\begin{array}{l}\text { 1. articulate the capabilities and } \\
\text { constraints of information developed } \\
\text { through various creation processes }\end{array}$} & $\begin{array}{l}\text { CV-02: Evaluate the advantages and limitations of } \\
\text { various technological approaches to mapping. }\end{array}$ \\
\hline & $\begin{array}{l}\text { CV-40: Describe the technological enablements and } \\
\text { constraints that make mobile a unique design context for } \\
\text { cartography and visualization. (Ricker and Roth 2018) }\end{array}$ \\
\hline & $\begin{array}{l}\text { FC-28: Describe a scenario in which data from a } \\
\text { secondary source may pose obstacles to effective and } \\
\text { efficient use. }\end{array}$ \\
\hline \multirow[t]{3}{*}{$\begin{array}{l}\text { 2. assess the fit between an information } \\
\text { product's creation process and a } \\
\text { particular information need }\end{array}$} & $\begin{array}{l}\text { CV-20: Compare and contrast the file formats suited to } \\
\text { presentation of maps on the Web to those suited to } \\
\text { publication in high resolution contexts. }\end{array}$ \\
\hline & $\begin{array}{l}\text { CV-23: Describe maps that can be used to find direction, } \\
\text { distance, or position, plan routes, calculate area or } \\
\text { volume, or describe shape. }\end{array}$ \\
\hline & $\begin{array}{l}\text { DA-16: Design a system for creating a given target spatial } \\
\text { data layer, including end user needs assessment, } \\
\text { geographic and attribute data characteristic and accuracy } \\
\text { specifications, collection, quality control, and processing } \\
\text { protocols, workflows, accuracy assessment and } \\
\text { documentation, and metadata development. (Bolstad } \\
2018 \text { ) }\end{array}$ \\
\hline
\end{tabular}




\begin{tabular}{|c|c|}
\hline \multirow{3}{*}{$\begin{array}{l}\text { 3. articulate the traditional and emerging } \\
\text { processes of information creation and } \\
\text { dissemination in a particular discipline }\end{array}$} & $\begin{array}{l}\text { CV-01: Describe how compilation, production, and } \\
\text { distribution methods used in map-making have evolved. }\end{array}$ \\
\hline & $\begin{array}{l}\text { CV-02: Explain how emerging technologies in related } \\
\text { fields (e.g., the stereoplotter, aerial and satellite imagery, } \\
\text { GPS and LiDAR, the World Wide Web, immersive and } \\
\text { virtual environments) have advanced cartography and } \\
\text { visualization methods. }\end{array}$ \\
\hline & $\begin{array}{l}\text { DC-36: Describe the georeferencing process including the } \\
\text { techniques and transformations necessary for the use of } \\
\text { historical maps. (Piovan 2019) }\end{array}$ \\
\hline \multirow{3}{*}{$\begin{array}{l}\text { 4. recognize that information may be } \\
\text { perceived differently based on the format } \\
\text { in which it is packaged }\end{array}$} & $\begin{array}{l}\text { AM-59: Illustrate the impact of vector/raster/vector } \\
\text { conversions on the quality of a dataset. }\end{array}$ \\
\hline & $\begin{array}{l}\text { CV-06: Compare multiple map projections to explain the } \\
\text { difference in distortion patterns, and how the maps would } \\
\text { be suited for different analysis or visualization purposes. } \\
\text { (Battersby 2017) }\end{array}$ \\
\hline & $\begin{array}{l}\text { CV-12: Differentiate the interpretation of a series of three } \\
\text { maps and a single multivariate map, each representing the } \\
\text { same three related variables. }\end{array}$ \\
\hline \multirow[t]{3}{*}{$\begin{array}{l}\text { 5. recognize the implications of } \\
\text { information formats that contain static or } \\
\text { dynamic information }\end{array}$} & $\begin{array}{l}\text { AM-90: Name key visual analytics approaches for } \\
\text { analyzing movement data, and list their properties and } \\
\text { limitations. (Laube 2017) }\end{array}$ \\
\hline & $\begin{array}{l}\text { CV-17: Compare and contrast the relative advantages and } \\
\text { limitations of four ways to represent spatiotemporal } \\
\text { information: single static maps, multiple static maps, } \\
\text { single dynamic maps, and multiple dynamic maps. (Fish } \\
\text { 2018) }\end{array}$ \\
\hline & $\begin{array}{l}\text { CV-18: Compare and contrast different techniques for } \\
\text { representing uncertainty in maps (e.g., the use of static vs. } \\
\text { dynamic approaches). (Kinkeldey and Senaratne 2018) }\end{array}$ \\
\hline \multirow{3}{*}{$\begin{array}{l}\text { 6. monitor the value that is placed upon } \\
\text { different types of information products in } \\
\text { varying contexts }\end{array}$} & $\begin{array}{l}\text { DM-57: Formulate metadata for a graphic output that } \\
\text { would be distributed to the general public. }\end{array}$ \\
\hline & $\begin{array}{l}\text { FC-14: Outline the implications of differences in distance } \\
\text { calculations on real world applications of GIS, such as } \\
\text { routing and determining boundary lengths and service } \\
\text { areas. }\end{array}$ \\
\hline & $\begin{array}{l}\text { FC-21: Describe how resolution can affect study findings } \\
\text { and interpretations in environmental health risk } \\
\text { assessment. (Lam 2019) }\end{array}$ \\
\hline \multirow[t]{3}{*}{$\begin{array}{l}\text { 7. transfer knowledge of capabilities and } \\
\text { constraints to new types of information } \\
\text { products }\end{array}$} & $\begin{array}{l}\text { AM-02: Explain what is special (i.e., difficult) about } \\
\text { geospatial data analysis and why some traditional } \\
\text { statistical analysis techniques are not suited to geographic } \\
\text { problems. }\end{array}$ \\
\hline & $\begin{array}{l}\text { CV-03: Explain how data acquired from primary sources, } \\
\text { such as satellite imagery and GPS, differ from data } \\
\text { compiled from maps, such as DLGs. }\end{array}$ \\
\hline & $\begin{array}{l}\text { FC-25: Describe the causes of at least five different types } \\
\text { of errors (e.g., positional, attribute, temporal, logical } \\
\text { inconsistency, and incompleteness). }\end{array}$ \\
\hline \multirow{3}{*}{$\begin{array}{l}\text { 8. develop, in their own creation } \\
\text { processes, an understanding that their } \\
\text { choices impact the purposes for which the } \\
\text { information product will be used and the } \\
\text { message it conveys }\end{array}$} & $\begin{array}{l}\text { CV-07: Prepare different maps using the same map } \\
\text { components to produce maps with different purposes and } \\
\text { distinctive intellectual and visual hierarchies. (Tait 2018) }\end{array}$ \\
\hline & $\begin{array}{l}\text { CV-08: Evaluate the effectiveness of a map's symbology } \\
\text { based on the underlying nature of the data and the visual } \\
\text { variables used to represent those data. (White 2017) }\end{array}$ \\
\hline & $\begin{array}{l}\text { CV-26: Understand how decisions in the design of a map, } \\
\text { and the underlying data from which a map draws, affect } \\
\text { what users can know from the map. (Thatcher 2018) }\end{array}$ \\
\hline
\end{tabular}




\begin{tabular}{|c|c|}
\hline $\begin{array}{l}\text { B. Dispositions } \\
\text { Learners who are developing their } \\
\text { information literate abilities }\end{array}$ & \\
\hline \multirow[t]{2}{*}{$\begin{array}{l}\text { 1. are inclined to seek out characteristics } \\
\text { of information products that indicate the } \\
\text { underlying creation process }\end{array}$} & $\begin{array}{l}\text { AM-87: Describe the problem of conflation associated } \\
\text { with aggregation of data collected at different times, from } \\
\text { different sources, and to different scales and accuracy } \\
\text { requirements. }\end{array}$ \\
\hline & $\begin{array}{l}\text { DM-57: Interpret the elements of an existing metadata } \\
\text { document. }\end{array}$ \\
\hline \multirow[t]{2}{*}{$\begin{array}{l}\text { 2. value the process of matching an } \\
\text { information need with an appropriate } \\
\text { product }\end{array}$} & $\begin{array}{l}\text { AM-60: Resample raster data sets (e.g., terrain, satellite } \\
\text { imagery) to a resolution appropriate for a map of a } \\
\text { particular scale. }\end{array}$ \\
\hline & $\begin{array}{l}\text { AM-62: Explain the pitfalls of using data generalized for } \\
\text { small scale display in a large scale application. }\end{array}$ \\
\hline \multirow{2}{*}{$\begin{array}{l}\text { 3. accept that the creation of information } \\
\text { may begin initially through } \\
\text { communicating in a range of formats or } \\
\text { modes }\end{array}$} & $\begin{array}{l}\text { FC-05: Describe the limitations of various information } \\
\text { stores for representing geographic information, including } \\
\text { the mind, computers, graphics, and text. }\end{array}$ \\
\hline & $\begin{array}{l}\text { PD-05: Transfer data from primary and secondary sources } \\
\text { into the database. }\end{array}$ \\
\hline \multirow[t]{2}{*}{$\begin{array}{l}\text { 4. accept the ambiguity surrounding the } \\
\text { potential value of information creation } \\
\text { expressed in emerging formats or modes }\end{array}$} & $\begin{array}{l}\text { AM-38: Explain the outcome of an artificial intelligence } \\
\text { analysis (e.g., edge recognition), including a discussion of } \\
\text { what the human did not see that the computer identified } \\
\text { and vice versa. }\end{array}$ \\
\hline & $\begin{array}{l}\text { CV-16: Evaluate the extent to which a GeoWall or CAVE } \\
\text { does or does not enhance understanding of spatial data. }\end{array}$ \\
\hline \multirow[t]{2}{*}{$\begin{array}{l}\text { 5. resist the tendency to equate format } \\
\text { with the underlying creation process }\end{array}$} & $\begin{array}{l}\text { AM-56: Create a flowchart showing the sequence of } \\
\text { transformations on a data set (e.g., geometric and } \\
\text { radiometric correction and mosaicking of remotely sensed } \\
\text { data). }\end{array}$ \\
\hline & $\begin{array}{l}\text { FC-20: Demonstrate how different methods of data } \\
\text { classification for a single dataset can produce maps that } \\
\text { will be interpreted very differently by the user. }\end{array}$ \\
\hline \multirow[t]{2}{*}{$\begin{array}{l}\text { 6. understand that different methods of } \\
\text { information dissemination with different } \\
\text { purposes are available for their use }\end{array}$} & $\begin{array}{l}\text { CV-32: Describe the different purposes that cartograms } \\
\text { serve in relation to other thematic mapping techniques. } \\
\text { (Field 2017) }\end{array}$ \\
\hline & $\begin{array}{l}\text { DA-16: Demonstrate basic skills in digital cartography, } \\
\text { via the production of hardcopy and digital maps with } \\
\text { appropriate layout and information. (Bolstad 2018) }\end{array}$ \\
\hline
\end{tabular}

\section{Information Has Value}

\begin{tabular}{|l|l|}
\hline \multicolumn{1}{|c|}{ ACRL Framework } & \multicolumn{1}{c|}{ GIS\&T Body of Knowledge } \\
\hline $\begin{array}{l}\text { A. Knowledge Practices } \\
\text { Learners who are developing their } \\
\text { information literate abilities }\end{array}$ & \\
\hline $\begin{array}{l}\text { 1. give credit to the original ideas of } \\
\text { others through proper attribution and } \\
\text { citation }\end{array}$ & $\begin{array}{l}\text { AM-12: Discuss the origins of cartographic modeling } \\
\text { with reference to the work of Ian McHarg. }\end{array}$ \\
\cline { 2 - 2 } $\begin{array}{l}\text { CV-01: Explain how Bertin has influenced trends in } \\
\text { cartographic symbolization. }\end{array}$ \\
\hline $\begin{array}{l}\text { 2. understand that intellectual property is } \begin{array}{l}\text { legal and social construct that varies by } \\
\text { culture }\end{array} \\
\text { GS-07: Compare and contrast the consequences of } \\
\text { different national policies about rights to geospatial data } \\
\text { in terms of the real costs of spatial data, their coverage, } \\
\text { accuracy, uncertainty, reliability, validity, and } \\
\text { maintenance. }\end{array}$ \\
\cline { 2 - 2 } $\begin{array}{l}\text { GS-16: Discuss the production, maintenance, and use of } \\
\text { geospatial data by a government agency or private firm } \\
\text { from the perspectives of a taxpayer, a community } \\
\text { organization, and a member of a minority group. }\end{array}$ \\
\hline
\end{tabular}




\begin{tabular}{|c|c|}
\hline \multirow{2}{*}{$\begin{array}{l}\text { 3. articulate the purpose and } \\
\text { distinguishing characteristics of } \\
\text { copyright, fair use, open access, and the } \\
\text { public domain }\end{array}$} & $\begin{array}{l}\text { CV-03: Describe the copyright issues involved in various } \\
\text { cartographic source materials. }\end{array}$ \\
\hline & $\begin{array}{l}\text { GS-09: Explain the concept of "fair use" with regard to } \\
\text { geospatial information. }\end{array}$ \\
\hline \multirow{2}{*}{$\begin{array}{l}\text { 4. understand how and why some } \\
\text { individuals or groups of individuals may } \\
\text { be underrepresented or systematically } \\
\text { marginalized within the systems that } \\
\text { produce and disseminate information }\end{array}$} & $\begin{array}{l}\text { DC-22: Discuss the political, cultural, economic, and } \\
\text { geographic characteristics of various countries that } \\
\text { influence their adoption and use of GIS\&T. }\end{array}$ \\
\hline & $\begin{array}{l}\text { GS- } 05 \text { : Describe an example of "local knowledge" that is } \\
\text { unlikely to be represented in the geospatial data } \\
\text { maintained routinely by government agencies. }\end{array}$ \\
\hline \multirow[t]{2}{*}{$\begin{array}{l}\text { 5. recognize issues of access or lack of } \\
\text { access to information sources }\end{array}$} & $\begin{array}{l}\text { FC-35: Explain the importance and implications in } \\
\text { GIS\&T of at least } 3 \text { benefits of Openness in the following } \\
\text { areas: Open Data; Free and Open Source Software; and } \\
\text { Open Standards. (Moreno-Sanchez 2018) }\end{array}$ \\
\hline & $\begin{array}{l}\text { GS-22: Describe how inter-organization GIS portals may } \\
\text { impact or influence issues related to social equity, privacy } \\
\text { and data access. }\end{array}$ \\
\hline \multirow[t]{2}{*}{$\begin{array}{l}\text { 6. decide where and how their } \\
\text { information is published }\end{array}$} & $\begin{array}{l}\text { GS-04: Use activity based on individuals' location } \\
\text { information, such as adding data to a crowdsourced map } \\
\text { or using a map showing social media postings on specific } \\
\text { topics. (Kerski 2016) }\end{array}$ \\
\hline & $\begin{array}{l}\text { GS-24: Discuss different types of Citizen Science } \\
\text { activities (passive sensing, volunteer computing, } \\
\text { volunteer thinking, environmental and ecological } \\
\text { observation, participatory sensing, community/civic } \\
\text { science) and potential motivations (intrinsic and extrinsic } \\
\text { motives) participants may have to engage with projects. } \\
\text { (Rickles et al. 2017) }\end{array}$ \\
\hline \multirow[t]{2}{*}{$\begin{array}{l}\text { 7. understand how the commodification } \\
\text { of their personal information and online } \\
\text { interactions affects the information they } \\
\text { receive and the information they produce } \\
\text { or disseminate online }\end{array}$} & $\begin{array}{l}\text { DA-24: Describe how big data, continuous data tracking } \\
\text { and streaming, the Internet of things (IoT) and SoLoMo } \\
\text { marketing have enhanced enterprise knowledge of current } \\
\text { and potential customers. Explain how location analytics } \\
\text { tools have contributed to these technologies. (Miller } \\
\text { 2018) }\end{array}$ \\
\hline & $\begin{array}{l}\text { GS-04: Discuss how spatial data, GPS-enabled devices } \\
\text { such as smartphones, the Internet of Things (geolocated } \\
\text { objects that provide their location), and the Software as a } \\
\text { Service (SaaS) GIS model have combined to bring society } \\
\text { to its current high concern about location privacy. (Kerski } \\
\text { 2016) }\end{array}$ \\
\hline \multirow[t]{2}{*}{$\begin{array}{l}\text { 8. make informed choices regarding their } \\
\text { online actions in full awareness of issues } \\
\text { related to privacy and the } \\
\text { commodification of personal information }\end{array}$} & $\begin{array}{l}\text { CP-10: Discuss common geovisualization methods (e.g., } \\
\text { graphs and maps) and tools for mapping and visualizing } \\
\text { different components of social media data (e.g., geo-tags, } \\
\text { temporal information, and users). (Huang 2018) }\end{array}$ \\
\hline & $\begin{array}{l}\text { GS-04: Discuss societal benefits and potential societal } \\
\text { harm from the use of individuals' location information. } \\
\text { (Kerski 2016) }\end{array}$ \\
\hline \multicolumn{2}{|l|}{$\begin{array}{l}\text { B. Dispositions } \\
\text { Learners who are developing their } \\
\text { information literate abilities }\end{array}$} \\
\hline 1. respect the original ideas of others & $\begin{array}{l}\text { GS-08: Distinguish among the various intellectual } \\
\text { property rights, including copyright, patent, trademark, } \\
\text { business methods, and other rights. }\end{array}$ \\
\hline $\begin{array}{l}\text { 2. value the skills, time, and effort needed } \\
\text { to produce knowledge }\end{array}$ & $\begin{array}{l}\text { DC-21: Explain the ways in which metadata increases the } \\
\text { value of geospatial data. }\end{array}$ \\
\hline $\begin{array}{l}\text { 3. see themselves as contributors to the } \\
\text { information marketplace rather than only } \\
\text { consumers of it }\end{array}$ & $\begin{array}{l}\text { DM-57: Use a metadata utility to create a geospatial } \\
\text { metadata document for a digital database you created. }\end{array}$ \\
\hline
\end{tabular}


4. are inclined to examine their own information privilege
KE-06: Compare and contrast the needs, constraints, and opportunities of different types of institutions, such as corporations, non-profit organizations, government agencies, and educational institutions.

\section{Research as Inquiry}

\begin{tabular}{|c|c|}
\hline ACRL Framework & GIS\&T Body of Knowledge \\
\hline $\begin{array}{l}\text { A. Knowledge Practices } \\
\text { Learners who are developing their } \\
\text { information literate abilities }\end{array}$ & \\
\hline \multirow[t]{2}{*}{$\begin{array}{l}\text { 1. formulate questions for research based } \\
\text { on information gaps or on reexamination } \\
\text { of existing, possibly conflicting, } \\
\text { information }\end{array}$} & $\begin{array}{l}\text { CV-35: Use a geovisualization application to explore a } \\
\text { geospatial dataset. Note the geographic insights you find } \\
\text { and hypotheses worth pursuing with additional analysis } \\
\text { and visualization. (Çöltekin, Janetzko, and Fabrikant } \\
\text { 2018) }\end{array}$ \\
\hline & $\begin{array}{l}\text { DA-23: Develop recommendations and practical solutions } \\
\text { to help bridge the gap between ocean } \\
\text { science/management and GIS, including increased } \\
\text { integration of ocean data and improved analytical tools. } \\
\text { (Wright 2017) }\end{array}$ \\
\hline \multirow[t]{2}{*}{$\begin{array}{l}\text { 2. determine an appropriate scope of } \\
\text { investigation }\end{array}$} & $\begin{array}{l}\text { CV-03: List the data required to explore a specified } \\
\text { problem. }\end{array}$ \\
\hline & $\begin{array}{l}\text { KE- } 05 \text { : Create requirements reports for individual } \\
\text { potential applications in terms of the data, procedures, and } \\
\text { output needed. }\end{array}$ \\
\hline \multirow[t]{2}{*}{$\begin{array}{l}\text { 3. deal with complex research by } \\
\text { breaking complex questions into simple } \\
\text { ones, limiting the scope of investigations }\end{array}$} & $\begin{array}{l}\text { AM-02: Outline the sequence of tasks required to } \\
\text { complete the analytical process for a given spatial } \\
\text { problem. }\end{array}$ \\
\hline & $\begin{array}{l}\text { FC-13: State questions that can be solved by selecting } \\
\text { features based on location or spatial relationships. }\end{array}$ \\
\hline \multirow[t]{2}{*}{$\begin{array}{l}\text { 4. use various research methods, based on } \\
\text { need, circumstance, and type of inquiry }\end{array}$} & $\begin{array}{l}\text { GS-25: Differentiate decision problems by their } \\
\text { complexity, scope, nature of decision-makers, and } \\
\text { spatiality. (Rinner 2018) }\end{array}$ \\
\hline & $\begin{array}{l}\text { KE-30: Describe three applications of geospatial } \\
\text { technology for different workforce domains (e.g., first } \\
\text { responders, forestry, water resource management, } \\
\text { facilities management). }\end{array}$ \\
\hline \multirow[t]{2}{*}{$\begin{array}{l}\text { 5. monitor gathered information and } \\
\text { assess for gaps or weaknesses }\end{array}$} & $\begin{array}{l}\text { DM-70: Explain how to recognize contaminated data in } \\
\text { large datasets. (Usery 2019) }\end{array}$ \\
\hline & $\begin{array}{l}\text { KE-02: Identify geographic tasks for which particular } \\
\text { geospatial technologies are not adequate or sufficient. }\end{array}$ \\
\hline \multirow[t]{2}{*}{$\begin{array}{l}\text { 6. organize information in meaningful } \\
\text { ways }\end{array}$} & $\begin{array}{l}\text { CV-19: Develop a visualization for the exploration and } \\
\text { analysis of big data. (Poorthuis 2018) }\end{array}$ \\
\hline & $\begin{array}{l}\text { DM-18: Identify whether it is important to represent } \\
\text { temporal change in a particular GIS application. }\end{array}$ \\
\hline \multirow[t]{2}{*}{$\begin{array}{l}\text { 7. synthesize ideas gathered from } \\
\text { multiple sources }\end{array}$} & $\begin{array}{l}\text { CV-38: Schedule a user-centered design process for } \\
\text { acquiring feedback from target users throughout design } \\
\text { and development. (Ooms and Skarlatidou 2018) }\end{array}$ \\
\hline & $\begin{array}{l}\text { KE-05: Evaluate how external spatial data sources can be } \\
\text { incorporated into the business process. }\end{array}$ \\
\hline \multirow[t]{2}{*}{$\begin{array}{l}\text { 8. draw reasonable conclusions based on } \\
\text { the analysis and interpretation of } \\
\text { information }\end{array}$} & $\begin{array}{l}\text { AM-19: Select the appropriate statistical methods for the } \\
\text { analysis of given spatial datasets by first exploring them } \\
\text { using graphic methods. }\end{array}$ \\
\hline & $\begin{array}{l}\text { GS-11: Demonstrate the ability to reason about an ethical } \\
\text { challenge in the professional practice of GIS by } \\
\text { methodically analyzing an ethics case study. (DiBiase } \\
\text { 2017) }\end{array}$ \\
\hline
\end{tabular}




\begin{tabular}{|c|c|}
\hline $\begin{array}{l}\text { B. Dispositions } \\
\text { Learners who are developing their } \\
\text { information literate abilities }\end{array}$ & \\
\hline $\begin{array}{l}\text { 1. consider research as open-ended } \\
\text { exploration and engagement with } \\
\text { information }\end{array}$ & $\begin{array}{l}\text { AM-37: Explain how visual data exploration can be } \\
\text { combined with data mining techniques as a means of } \\
\text { discovering research hypotheses in large spatial datasets. }\end{array}$ \\
\hline $\begin{array}{l}\text { 2. appreciate that a question may appear } \\
\text { to be simple but still disruptive and } \\
\text { important to research }\end{array}$ & -- \\
\hline $\begin{array}{l}\text { 3. value intellectual curiosity in } \\
\text { developing questions and learning new } \\
\text { investigative methods }\end{array}$ & $\begin{array}{l}\text { AM-02: Discuss situations when it is desirable to adopt a } \\
\text { spatial approach to the analysis of data. }\end{array}$ \\
\hline $\begin{array}{l}\text { 4. maintain an open mind and a critical } \\
\text { stance }\end{array}$ & $\begin{array}{l}\text { GS-17: Differentiate applications that can make use of } \\
\text { common-sense principles of geography from those that } \\
\text { should not. }\end{array}$ \\
\hline $\begin{array}{l}\text { 5. value persistence, adaptability, and } \\
\text { flexibility and recognize that ambiguity } \\
\text { can benefit the research process }\end{array}$ & $\begin{array}{l}\text { GS-11: Demonstrate ethical creativity by posing multiple } \\
\text { possible solutions to an ethical challenge. Resist the } \\
\text { temptation to reduce such challenges to simplistic } \\
\text { dilemmas. (DiBiase 2017) }\end{array}$ \\
\hline $\begin{array}{l}\text { 6. seek multiple perspectives during } \\
\text { information gathering and assessment }\end{array}$ & $\begin{array}{l}\text { DA-09: Describe the four essential groups of people that } \\
\text { are needed for a collaborative geodesign project. (Ruddell } \\
\text { and Foster 2018) }\end{array}$ \\
\hline 7. seek appropriate help when needed & -- \\
\hline $\begin{array}{l}\text { 8. follow ethical and legal guidelines in } \\
\text { gathering and using information }\end{array}$ & $\begin{array}{l}\text { DC-24: Understand the requirements for legal operation } \\
\text { of UAS for data collection purposes. (Mathews and } \\
\text { Frazier 2017) }\end{array}$ \\
\hline $\begin{array}{l}\text { 9. demonstrate intellectual humility (i.e., } \\
\text { recognize their own intellectual or } \\
\text { experiential limitations) }\end{array}$ & -- \\
\hline
\end{tabular}

\section{Scholarship as Conversation}

\begin{tabular}{|l|l|}
\hline \multicolumn{1}{|c|}{ ACRL Framework } & \multicolumn{1}{c|}{ GIS\&T Body of Knowledge } \\
\hline $\begin{array}{l}\text { A. Knowledge Practices } \\
\text { Learners who are developing their } \\
\text { information literate abilities }\end{array}$ & \\
\hline $\begin{array}{l}\text { 1. cite the contributing work of others in } \\
\text { their own information production }\end{array}$ & $\begin{array}{l}\text { AM-32: Explain Anselin's typology of spatial } \\
\text { autoregressive models. }\end{array}$ \\
\cline { 2 - 2 } & $\begin{array}{l}\text { CV-02: Explain how MacEachren's Cartography-cubed } \\
\text { (C3) concept can be used to understand the evolving role } \\
\text { of cartography and visualization. }\end{array}$ \\
\hline $\begin{array}{l}\text { 2. contribute to scholarly conversation at } \\
\text { an appropriate level, such as local online } \\
\text { community, guided discussion, } \\
\text { undergraduate research journal, } \\
\text { conference presentation/poster session }\end{array}$ & \\
\hline $\begin{array}{l}\text { 3. identify barriers to entering scholarly } \\
\text { conversation via various venues }\end{array}$ & $\begin{array}{l}\text { DA-11: Discuss the epistemological and ontological } \\
\text { barriers to the use of GIS\&T in the humanities, and } \\
\text { possible solutions. (Giordano 2019) }\end{array}$ \\
\cline { 2 - 2 } & $\begin{array}{l}\text { DA-23: Identify, understand, and help overcome the } \\
\text { barriers to use of scientific oceanographic data by GIS } \\
\text { users, as well as increase the use of GIS tools by ocean } \\
\text { science and resource management users. (Wright 2017) }\end{array}$ \\
\hline
\end{tabular}




\begin{tabular}{|c|c|}
\hline \multirow[t]{2}{*}{$\begin{array}{l}\text { 4. critically evaluate contributions made } \\
\text { by others in participatory information } \\
\text { environments }\end{array}$} & $\begin{array}{l}\text { CV-19: Critique a big data visualization by how well it } \\
\text { overcame computational, visual, and ethical challenges. } \\
\text { (Poorthuis 2018) }\end{array}$ \\
\hline & $\begin{array}{l}\text { CV-26: Identify and critique a map created through } \\
\text { surveillant approaches to map making. Identify and } \\
\text { critique a map created through sousveillant or } \\
\text { participatory approaches. (Thatcher 2018) }\end{array}$ \\
\hline \multirow[t]{2}{*}{$\begin{array}{l}\text { 5. identify the contribution that particular } \\
\text { articles, books, and other scholarly pieces } \\
\text { make to disciplinary knowledge }\end{array}$} & $\begin{array}{l}\text { DA-11: Discuss the precursors to the spatial turn in the } \\
\text { humanities, and specifically the ideas of chronotope and } \\
\text { geohistoire, and Hägerstrand's time-geography. } \\
\text { (Giordano 2019) }\end{array}$ \\
\hline & $\begin{array}{l}\text { FC-30: Describe the contributions of McHarg and other } \\
\text { practitioners in developing geographic analysis methods } \\
\text { later incorporated into GIS. }\end{array}$ \\
\hline \multirow[t]{2}{*}{$\begin{array}{l}\text { 6. summarize the changes in scholarly } \\
\text { perspective over time on a particular topic } \\
\text { within a specific discipline }\end{array}$} & $\begin{array}{l}\text { CV-36: Describe the evolution of geovisual analytics as a } \\
\text { sub-field in GIScience and its linkages to fields outside of } \\
\text { Geography. (Robinson 2017) }\end{array}$ \\
\hline & $\begin{array}{l}\text { FC-31: Describe the major research foci in GIS and } \\
\text { related fields in the } 1970 \mathrm{~s}, 1980 \mathrm{~s}, 1990 \mathrm{~s} \text {, and } 2000 \mathrm{~s} \text {. }\end{array}$ \\
\hline \multirow[t]{2}{*}{$\begin{array}{l}\text { 7. recognize that a given scholarly work } \\
\text { may not represent the only or even the } \\
\text { majority perspective on the issue }\end{array}$} & $\begin{array}{l}\text { AM-05: Describe the complexity and uncertainty in } \\
\text { neighborhood definition, incorporating the idea of no } \\
\text { consensus definition to fit all contexts. (Mu and Holloway } \\
\text { 2019) }\end{array}$ \\
\hline & $\begin{array}{l}\text { GS-13: Present GIScience scholars' and theorists' } \\
\text { responses to external critiques of GIS. (Leszczynski 2017) }\end{array}$ \\
\hline \multicolumn{2}{|l|}{$\begin{array}{l}\text { B. Dispositions } \\
\text { Learners who are developing their } \\
\text { information literate abilities }\end{array}$} \\
\hline $\begin{array}{l}\text { 1. recognize they are often entering into } \\
\text { an ongoing scholarly conversation and } \\
\text { not a finished conversation }\end{array}$ & $\begin{array}{l}\text { FC-37: Enumerate past, contemporary, and still-to-be- } \\
\text { researched properties of spatial autocorrelation. (Griffith } \\
\text { 2017) }\end{array}$ \\
\hline $\begin{array}{l}\text { 2. seek out conversations taking place in } \\
\text { their research area }\end{array}$ & $\begin{array}{l}\text { KE-29: Discuss the value or effect of participation in } \\
\text { societies, conferences, and informal communities to } \\
\text { entities managing enterprise GIS. }\end{array}$ \\
\hline $\begin{array}{l}\text { 3. see themselves as contributors to } \\
\text { scholarship rather than only consumers of } \\
\text { it }\end{array}$ & $\begin{array}{l}\text { FC-35: Research and present a benefit of Openness in } \\
\text { GIS\&T that is debated, questioned, or that has been } \\
\text { highlighted as requiring more research. (Moreno-Sanchez } \\
\text { 2018) }\end{array}$ \\
\hline $\begin{array}{l}\text { 4. recognize that scholarly conversations } \\
\text { take place in various venues }\end{array}$ & $\begin{array}{l}\text { CP-05: Explain how an understanding of use of current } \\
\text { and proposed technology in other organizations can aid in } \\
\text { implementing a GIS. }\end{array}$ \\
\hline $\begin{array}{l}\text { 5. suspend judgment on the value of a } \\
\text { particular piece of scholarship until the } \\
\text { larger context for the scholarly } \\
\text { conversation is better understood }\end{array}$ & $\begin{array}{l}\text { FC-07: Discuss the contributions that different } \\
\text { perspectives on the nature of space bring to an } \\
\text { understanding of geographic phenomenon. }\end{array}$ \\
\hline $\begin{array}{l}\text { 6. understand the responsibility that } \\
\text { comes with entering the conversation } \\
\text { through participatory channels }\end{array}$ & $\begin{array}{l}\text { CP-14: Critically discuss some societal effects stemming } \\
\text { from the web-enabled shift of spatial data production } \\
\text { from experts to laypersons (i.e., the rise of } \\
\text { "neogeography"). (Quinn 2018) }\end{array}$ \\
\hline $\begin{array}{l}\text { 7. value user-generated content and } \\
\text { evaluate contributions made by others }\end{array}$ & $\begin{array}{l}\text { CV-24: Evaluate the effectiveness of a map for its } \\
\text { audience and purpose. }\end{array}$ \\
\hline $\begin{array}{l}\text { 8. recognize that systems privilege } \\
\text { authorities and that not having a fluency } \\
\text { in the language and process of a } \\
\text { discipline disempowers their ability to } \\
\text { participate and engage }\end{array}$ & $\begin{array}{l}\text { GS-17: Effectively communicate the design, procedures, } \\
\text { and results of GIS projects to non-GIS audiences (clients, } \\
\text { managers, general public). }\end{array}$ \\
\hline
\end{tabular}




\begin{tabular}{|c|c|}
\hline ACRL Framework & GIS\&T Body of Knowledge \\
\hline \multicolumn{2}{|l|}{$\begin{array}{l}\text { A. Knowledge Practices } \\
\text { Learners who are developing their } \\
\text { information literate abilities }\end{array}$} \\
\hline \multirow{2}{*}{$\begin{array}{l}\text { 1. determine the initial scope of the task } \\
\text { required to meet their information needs }\end{array}$} & CV-03: Compile a map using at least three data sources. \\
\hline & $\begin{array}{l}\text { DC-36: Obtain historical maps in digital form and prepare } \\
\text { them for georeferencing. (Piovan 2019) }\end{array}$ \\
\hline \multirow{2}{*}{$\begin{array}{l}\text { 2. identify interested parties, such as } \\
\text { scholars, organizations, governments, and } \\
\text { industries, who might produce } \\
\text { information about a topic and then } \\
\text { determine how to access that information }\end{array}$} & $\begin{array}{l}\text { DA-05: List and describe the types of data maintained by } \\
\text { local governments. }\end{array}$ \\
\hline & $\begin{array}{l}\text { KE-28: Select and describe the leading trade journals } \\
\text { serving the GIS\&T community. }\end{array}$ \\
\hline \multirow{2}{*}{$\begin{array}{l}\text { 3. utilize divergent (e.g., brainstorming) } \\
\text { and convergent (e.g., selecting the best } \\
\text { source) thinking when searching }\end{array}$} & $\begin{array}{l}\text { AM-69: Demonstrate how to examine the CA research } \\
\text { literature. (Clarke 2017) }\end{array}$ \\
\hline & $\begin{array}{l}\text { KE-08: Identify potential sources of data (free or } \\
\text { commercial) needed for a particular application or } \\
\text { enterprise. }\end{array}$ \\
\hline \multirow[t]{2}{*}{$\begin{array}{l}\text { 4. match information needs and search } \\
\text { strategies to appropriate search tools }\end{array}$} & $\begin{array}{l}\text { DC-28: Link Census demographic data to the appropriate } \\
\text { TIGER geography within GIS. (Castagneri 2019) }\end{array}$ \\
\hline & $\begin{array}{l}\text { KE-28: Describe the leading academic journals serving } \\
\text { the GIS\&T community. }\end{array}$ \\
\hline $\begin{array}{l}\text { 5. design and refine needs and search } \\
\text { strategies as necessary, based on search } \\
\text { results }\end{array}$ & $\begin{array}{l}\text { DA-16: Identify, download, prepare, and interpret public } \\
\text { data sources relevant to forestry, including USDA } \\
\text { Agricultural Research Service National Aerial Imagery } \\
\text { Program aerial photographs, NRCS SSURGO soils data, } \\
\text { USGS digital elevation data, USDA National Agricultural } \\
\text { Service Crop Data Layer data, USFWS National } \\
\text { Wetlands Inventory data, and USGS National } \\
\text { Hydrography Dataset streams, rivers, and lakes data. } \\
\text { (Bolstad 2018) }\end{array}$ \\
\hline \multirow{2}{*}{$\begin{array}{l}\text { 6. understand how information systems } \\
\text { (i.e., collections of recorded information) } \\
\text { are organized in order to access relevant } \\
\text { information }\end{array}$} & $\begin{array}{l}\text { DC-28: Retrieve relevant census data from the Census } \\
\text { website. (Castagneri 2019) }\end{array}$ \\
\hline & $\begin{array}{l}\text { DM-60: Differentiate text-based search and map-based } \\
\text { search. (Hu and Li 2017) }\end{array}$ \\
\hline $\begin{array}{l}\text { 7. use different types of searching } \\
\text { language (e.g., controlled vocabulary, } \\
\text { keywords, natural language) } \\
\text { appropriately }\end{array}$ & $\begin{array}{l}\text { DM-58: Describe a domain ontology or vocabulary (i.e., } \\
\text { land use classification systems, surveyor codes, data } \\
\text { dictionaries, place names, or benthic habitat classification } \\
\text { system). }\end{array}$ \\
\hline $\begin{array}{l}\text { 8. manage searching processes and results } \\
\text { effectively }\end{array}$ & $\begin{array}{l}\text { KE-28: Develop a bibliography of scholarly and } \\
\text { professional articles and/or books that are relevant to a } \\
\text { particular GIS\&T project. }\end{array}$ \\
\hline \multicolumn{2}{|l|}{$\begin{array}{l}\text { B. Dispositions } \\
\text { Learners who are developing their } \\
\text { information literate abilities }\end{array}$} \\
\hline 1. exhibit mental flexibility and creativity & -- \\
\hline $\begin{array}{l}\text { 2. understand that first attempts at } \\
\text { searching do not always produce } \\
\text { adequate results }\end{array}$ & -- \\
\hline $\begin{array}{l}\text { 3. realize that information sources vary } \\
\text { greatly in content and format and have } \\
\text { varying relevance and value, depending } \\
\text { on the needs and nature of the search }\end{array}$ & $\begin{array}{l}\text { KE-25: Find or create training resources appropriate for } \\
\text { GIS\&T workforce in a local government organization. }\end{array}$ \\
\hline $\begin{array}{l}\text { 4. seek guidance from experts, such as } \\
\text { librarians, researchers, and professionals }\end{array}$ & $\begin{array}{l}\text { DC-36: Plan the acquisition of historical maps both online } \\
\text { and in archives, libraries and other repositories. (Piovan } \\
\text { 2019) }\end{array}$ \\
\hline
\end{tabular}


5. recognize the value of browsing and other serendipitous methods of information gathering

6. persist in the face of search challenges, and know when they have enough information to complete the information task 
Appendix 2. Alignment between GIS\&T Body of Knowledge topics and each of the six ACRL frames (indicated by an X).

\begin{tabular}{|c|c|c|c|c|c|c|}
\hline & \multicolumn{6}{|c|}{ Frame } \\
\hline Topic & $\mathbf{A C}$ & IC & IV & RI & SC & SE \\
\hline AM-02 - Analytical approaches & & $\mathrm{X}$ & & $\mathrm{X}$ & & \\
\hline AM-04 - Overlay & & $\mathrm{X}$ & & $\mathrm{X}$ & & \\
\hline AM-05 - Neighborhoods & & & & & $\mathrm{X}$ & \\
\hline AM-06 - Map algebra & & $\mathrm{X}$ & & $\mathrm{X}$ & & \\
\hline AM-07 - Point pattern analysis & & & & & $\mathrm{X}$ & \\
\hline AM-10 - Spatial interaction & & & & & $\mathrm{X}$ & \\
\hline AM-12 - Cartographic modeling & & & $\mathrm{X}$ & $\mathrm{X}$ & $\mathrm{X}$ & \\
\hline AM-15 - Calculating surface derivatives & & $\mathrm{X}$ & & & & \\
\hline AM-16 - Interpolation methods & $\mathrm{X}$ & $\mathrm{X}$ & & & & \\
\hline AM-19 - Exploratory data analysis (EDA) & & & & $\mathrm{X}$ & & \\
\hline AM-22 - Global measures of spatial association & & & $\mathrm{X}$ & & $\mathrm{X}$ & \\
\hline AM-26 - Spatial sampling for statistical analysis & & $\mathrm{X}$ & & $\mathrm{X}$ & & \\
\hline AM-32 - Spatial autoregressive models & & & $\mathrm{X}$ & & $\mathrm{X}$ & \\
\hline AM-36 - Data mining approaches & & & & $\mathrm{X}$ & & \\
\hline AM-37 - Knowledge discovery & & $\mathrm{X}$ & & $\mathrm{X}$ & & \\
\hline AM-38 - Pattern recognition & $\mathrm{X}$ & $\mathrm{X}$ & & & & \\
\hline AM-40 - Least-cost (shortest) path analysis & $\mathrm{X}$ & & & & & \\
\hline AM-42 - The classic transportation problem & & & & & $\mathrm{X}$ & \\
\hline AM-56 - Impacts of transformations & & $\mathrm{X}$ & & & & \\
\hline AM-57 - Data conversion & & $\mathrm{X}$ & & & & \\
\hline AM-59 - Vector-to-raster and raster-to-vector conversions & & $\mathrm{X}$ & & & & \\
\hline AM-60 - Raster resampling & & $\mathrm{X}$ & & & & \\
\hline AM-61 - Coordinate transformations & & $\mathrm{X}$ & & & & \\
\hline AM-62 - Approaches to point, line, and area generalization & & $\mathrm{X}$ & & & & \\
\hline AM-68 - Rule learning for spatial data mining & & $\mathrm{X}$ & & & & \\
\hline AM-69 - Cellular automata & & & & & $\mathrm{X}$ & $\mathrm{X}$ \\
\hline $\begin{array}{l}\text { AM- } 80 \text { - Capturing spatiotemporal dynamics in computational } \\
\text { modeling }\end{array}$ & & & & $\mathrm{X}$ & & \\
\hline AM-87 - Problems of currency, source, and scale & & $\mathrm{X}$ & & & & \\
\hline AM-90 - Computational movement analysis & & $\mathrm{X}$ & & & & \\
\hline CP-01 - Software systems & & & $\mathrm{X}$ & $\mathrm{X}$ & & $\mathrm{X}$ \\
\hline CP-04 - Artificial intelligence & & & & & & $\mathrm{X}$ \\
\hline CP-05 - Technology transfer & & & $\mathrm{X}$ & & $\mathrm{X}$ & \\
\hline CP-07 - Cyberinfrastructure & & & & & $\mathrm{X}$ & \\
\hline CP-10 - Social media analytics & & $\mathrm{X}$ & $\mathrm{X}$ & $\mathrm{X}$ & & \\
\hline CP-12 - Location-based services & & $\mathrm{X}$ & $\mathrm{X}$ & & & \\
\hline CP-14 - Web GIS & $\mathrm{X}$ & & $\mathrm{X}$ & & $\mathrm{X}$ & \\
\hline CP-29 - Enterprise GIS & & & $\mathrm{X}$ & & & \\
\hline CV-01 - Cartography and science & $\mathrm{X}$ & $\mathrm{X}$ & $\mathrm{X}$ & & $\mathrm{X}$ & \\
\hline CV-02 - Cartography and technology & & $\mathrm{X}$ & $\mathrm{X}$ & & $\mathrm{X}$ & \\
\hline CV-03 - Vector formats and sources & $\mathrm{X}$ & $\mathrm{X}$ & $\mathrm{X}$ & $\mathrm{X}$ & & $\mathrm{X}$ \\
\hline CV-04 - Scale and generalization & & $\mathrm{X}$ & & & & \\
\hline $\begin{array}{l}\text { CV-05 - Statistical mapping (enumeration, normalization, } \\
\text { classification) }\end{array}$ & & $\mathrm{X}$ & & & & \\
\hline CV-06 - Map projections & & $\mathrm{X}$ & & & & \\
\hline CV-07 - Visual hierarchy and layout & & $\mathrm{X}$ & & & & \\
\hline CV-08 - Symbolization and the visual variables & & $\mathrm{X}$ & & & $\mathrm{X}$ & \\
\hline CV-09 - Color theory & & $\mathrm{X}$ & & & & \\
\hline CV-11 - Common thematic map types & & $\mathrm{X}$ & & & & \\
\hline CV-12 - Bivariate and multivariate maps & & $\mathrm{X}$ & & & & \\
\hline CV-13 - User interface and user experience (UI/UX) design & & $\mathrm{X}$ & & $\mathrm{X}$ & & \\
\hline CV-15 - Web mapping & & $\mathrm{X}$ & & & & $\mathrm{X}$ \\
\hline
\end{tabular}




\begin{tabular}{|c|c|c|c|c|c|c|}
\hline & \multicolumn{6}{|c|}{ Frame } \\
\hline Topic & $\mathbf{A C}$ & IC & IV & RI & SC & SE \\
\hline CV-16 - Virtual and immersive environments & & $\mathrm{X}$ & & & & \\
\hline CV-17 - Spatiotemporal representation & & $\mathrm{X}$ & & & & \\
\hline CV-18 - Representing uncertainty & & $\mathrm{X}$ & & & & \\
\hline CV-19 - Big data visualization & & $\mathrm{X}$ & $\mathrm{X}$ & $\mathrm{X}$ & $\mathrm{X}$ & \\
\hline CV-20 - Raster formats and sources & & $\mathrm{X}$ & & & & \\
\hline CV-21 - Map reading & & $\mathrm{X}$ & & & & \\
\hline CV-23 - Map analysis & & $\mathrm{X}$ & & & & \\
\hline CV-24 - User-centered design and evaluation & & $\mathrm{X}$ & & & $\mathrm{X}$ & \\
\hline CV-25 - Metadata, quality, and uncertainty & $\mathrm{X}$ & $\mathrm{X}$ & & & $\mathrm{X}$ & \\
\hline CV-26 - Cartography and power & $\mathrm{X}$ & $\mathrm{X}$ & & & $\mathrm{X}$ & \\
\hline CV-27 - Cartography and art & $\mathrm{X}$ & & & & $\mathrm{X}$ & \\
\hline CV-32 - Cartograms & & $\mathrm{X}$ & & & $\mathrm{X}$ & \\
\hline CV-35 - Geovisualization & & $\mathrm{X}$ & & $\mathrm{X}$ & & \\
\hline CV-36 - Geovisual analytics & & $\mathrm{X}$ & & $\mathrm{X}$ & $\mathrm{X}$ & \\
\hline CV-38 - Usability engineering \& evaluation & & & & $\mathrm{X}$ & $\mathrm{X}$ & \\
\hline CV-40 - Mobile maps and responsive design & & $\mathrm{X}$ & & & & \\
\hline DA-01 - GIS\&T and agriculture & & $\mathrm{X}$ & & $\mathrm{X}$ & & \\
\hline DA-04 - GIS\&T and civil engineering & & & & & & $\mathrm{X}$ \\
\hline DA-05 - Applications in local government & $\mathrm{X}$ & & $\mathrm{X}$ & & & $\mathrm{X}$ \\
\hline DA-06 - Applications in state government & $\mathrm{X}$ & & $\mathrm{X}$ & & & $\mathrm{X}$ \\
\hline DA-07 - Applications in federal government & $\mathrm{X}$ & & $\mathrm{X}$ & & & $\mathrm{X}$ \\
\hline DA-08 - GIS\&T and archaeology & & & & & & $\mathrm{X}$ \\
\hline DA-09 - GIS\&T and geodesign & $\mathrm{X}$ & & & $\mathrm{X}$ & & \\
\hline DA-10 - GIS\&T and real estate & & $\mathrm{X}$ & & & & \\
\hline DA-11 - GIS\&T and the digital humanities & & & & & $\mathrm{X}$ & $\mathrm{X}$ \\
\hline DA-16 - GIS\&T and forestry & $\mathrm{X}$ & $\mathrm{X}$ & & $\mathrm{X}$ & & $\mathrm{X}$ \\
\hline DA-23 - GIS\&T and marine science & & & $\mathrm{X}$ & $\mathrm{X}$ & $\mathrm{X}$ & \\
\hline DA-24 - GIS\&T and marketing & & $\mathrm{X}$ & $\mathrm{X}$ & & & $\mathrm{X}$ \\
\hline DA-25 - Geospatial intelligence and national security & & & & & $\mathrm{X}$ & \\
\hline DA-33 - GIS\&T in urban and regional planning & $\mathrm{X}$ & $\mathrm{X}$ & & $\mathrm{X}$ & & \\
\hline DA-37 - GIS\&T and epidemiology & & $\mathrm{X}$ & $\mathrm{X}$ & $\mathrm{X}$ & $\mathrm{X}$ & $\mathrm{X}$ \\
\hline DA-38 - GIS\&T and retail business & $\mathrm{X}$ & & & & $\mathrm{X}$ & $\mathrm{X}$ \\
\hline DC-03 - Global Positioning System & & $\mathrm{X}$ & $\mathrm{X}$ & & & \\
\hline DC-09 - Field data technologies & & $\mathrm{X}$ & & & & \\
\hline DC-10 - Aerial photography: History and georeferencing & & $\mathrm{X}$ & & & $\mathrm{X}$ & \\
\hline DC-13 - Stereoscopy and orthoimagery & & $\mathrm{X}$ & & & & \\
\hline DC-14 - Vector data extraction & & $\mathrm{X}$ & & & & \\
\hline DC-16 - Nature of multispectral image data & & $\mathrm{X}$ & & & & \\
\hline DC-18 - Algorithms and processing & & $\mathrm{X}$ & & & & \\
\hline DC-21 - Spatial data sharing among organizations & & & $\mathrm{X}$ & & & \\
\hline $\begin{array}{l}\text { DC-22 - Federal agencies and national and international } \\
\text { organizations and programs }\end{array}$ & $\mathrm{X}$ & & $\mathrm{X}$ & & & \\
\hline DC-24 - Unmanned aerial systems (UAS) & & $\mathrm{X}$ & $\mathrm{X}$ & $\mathrm{X}$ & & $\mathrm{X}$ \\
\hline DC-26 - Remote sensing platforms & & & & & $\mathrm{X}$ & $\mathrm{X}$ \\
\hline DC-28 - United States census data & $\mathrm{X}$ & $\mathrm{X}$ & & & & $\mathrm{X}$ \\
\hline DC-36 - Historical maps in GIS & & $\mathrm{X}$ & & & & $\mathrm{X}$ \\
\hline DM-07 - The raster data model & & $\mathrm{X}$ & & & & \\
\hline DM-18 - Spatio-temporal GIS & & $\mathrm{X}$ & & $\mathrm{X}$ & & \\
\hline DM-19 - Modeling uncertainty & & $\mathrm{X}$ & & $\mathrm{X}$ & & \\
\hline DM-20 - Discrete entities & & & & $\mathrm{X}$ & $\mathrm{X}$ & \\
\hline DM-21 - Modeling three-dimensional (3D) entities & & $\mathrm{X}$ & & & & \\
\hline DM-28 - Topological relationships & & & & & $\mathrm{X}$ & \\
\hline DM-30 - Vagueness & & $\mathrm{X}$ & & & & \\
\hline DM-32 - Error-based uncertainty & & $\mathrm{X}$ & & & & \\
\hline DM-34 - Conceptual data models & & $\mathrm{X}$ & & $\mathrm{X}$ & & \\
\hline DM-44 - Approximating the Earth's shape with geoids & $\mathrm{X}$ & & & & & \\
\hline
\end{tabular}




\begin{tabular}{|c|c|c|c|c|c|c|}
\hline & \multicolumn{6}{|c|}{ Frame } \\
\hline Topic & $\mathbf{A C}$ & IC & IV & RI & SC & $\mathbf{S E}$ \\
\hline DM-48 - Plane coordinate systems & $\mathrm{X}$ & $\mathrm{X}$ & & & & \\
\hline DM-51 - Vertical datums & & & & & $\mathrm{X}$ & \\
\hline DM-52 - Horizontal datums & & & & & $\mathrm{X}$ & \\
\hline DM-56 - Georegistration & & $\mathrm{X}$ & & & & \\
\hline DM-57 - Metadata & & $\mathrm{X}$ & $\mathrm{X}$ & & & \\
\hline DM-58 - Content standards & & & $\mathrm{X}$ & & & $\mathrm{X}$ \\
\hline DM-60 - Spatial data infrastructures & & $\mathrm{X}$ & $\mathrm{X}$ & & & $\mathrm{X}$ \\
\hline DM-62 - Database administration & & & $\mathrm{X}$ & & & \\
\hline DM-65 - Spatial data uncertainty & & $\mathrm{X}$ & & & & \\
\hline DM-69 - Exchange specifications & & $\mathrm{X}$ & & & & \\
\hline DM-70 - Problems of large spatial databases & & $\mathrm{X}$ & & $\mathrm{X}$ & & \\
\hline FC-01 - Metaphysics and ontology & $\mathrm{X}$ & & & & & \\
\hline FC-02 - Epistemology & $\mathrm{X}$ & & & & & \\
\hline FC-03 - Philosophical perspectives & $\mathrm{X}$ & & & & $\mathrm{X}$ & \\
\hline FC-04 - Perception and cognition of geographic phenomena & & $\mathrm{X}$ & & & $\mathrm{X}$ & \\
\hline FC-05 - From concepts to data & & $\mathrm{X}$ & & & & \\
\hline FC-06 - Place and landscape & $\mathrm{X}$ & & & & $\mathrm{X}$ & \\
\hline FC-07 - Space & & $\mathrm{X}$ & & & $\mathrm{X}$ & \\
\hline FC-08 - Time & & $\mathrm{X}$ & & $\mathrm{X}$ & & \\
\hline FC-10 - Properties & & & & & $\mathrm{X}$ & \\
\hline FC-13 - Spatial queries & & & & $\mathrm{X}$ & & \\
\hline FC-14 - Distance, length, and direction & & $\mathrm{X}$ & & & & \\
\hline FC-16 - Area and region & & $\mathrm{X}$ & & & & \\
\hline FC-20 - The power of maps & $\mathrm{X}$ & $\mathrm{X}$ & & & & \\
\hline FC-21 - Resolution & & $\mathrm{X}$ & & & & \\
\hline FC-22 - Geometric primitives & & $\mathrm{X}$ & & & & \\
\hline FC-25 - Error & & $\mathrm{X}$ & & & & \\
\hline FC-26 - Problems of scale and zoning & & $\mathrm{X}$ & & & & \\
\hline FC-28 - Primary and secondary data sources & $\mathrm{X}$ & $\mathrm{X}$ & & & & \\
\hline FC-29 - Public sector origins & $\mathrm{X}$ & & & & $\mathrm{X}$ & \\
\hline FC-30 - Private sector origins & & & $\mathrm{X}$ & & $\mathrm{X}$ & $\mathrm{X}$ \\
\hline FC-31 - Academic origins & & & & & $\mathrm{X}$ & $\mathrm{X}$ \\
\hline FC-32 - Learning from experience & & & $\mathrm{X}$ & & $\mathrm{X}$ & \\
\hline FC-35 - Openness & & & $\mathrm{X}$ & & $\mathrm{X}$ & $\mathrm{X}$ \\
\hline FC-37 - Spatial autocorrelation & & & & & $\mathrm{X}$ & \\
\hline GS-02 - Contract law & & & $\mathrm{X}$ & & & \\
\hline GS-04 - Location privacy & & & $\mathrm{X}$ & & & \\
\hline GS-05 - Public participation in governing & $\mathrm{X}$ & & $\mathrm{X}$ & & & \\
\hline GS-06 - Public participation GIS & $\mathrm{X}$ & & $\mathrm{X}$ & & & \\
\hline GS-07 - Property regimes & $\mathrm{X}$ & & $\mathrm{X}$ & & & \\
\hline GS-08 - Mechanisms of control of geospatial information & & & $\mathrm{X}$ & & & \\
\hline GS-09 - Enforcing control & & & $\mathrm{X}$ & & & \\
\hline GS-10 - Balancing data access, security, and privacy & & & $\mathrm{X}$ & & & \\
\hline GS-11 - Professional and practical ethics of GIS\&T & $\mathrm{X}$ & & & $\mathrm{X}$ & & \\
\hline GS-12 - Codes of ethics for geospatial professionals & $\mathrm{X}$ & & & & & \\
\hline GS-13 - Epistemological critiques & & & & & $\mathrm{X}$ & \\
\hline GS-15 - Feminist critiques of GIS & $\mathrm{X}$ & & & & & \\
\hline GS-16 - Social critiques & $\mathrm{X}$ & & $\mathrm{X}$ & & & \\
\hline GS-17 - Common-sense geographies & $\mathrm{X}$ & $\mathrm{X}$ & $\mathrm{X}$ & $\mathrm{X}$ & $\mathrm{X}$ & \\
\hline GS-18 - Cultural influences & $\mathrm{X}$ & & & & & \\
\hline GS-19 - Political influences & $\mathrm{X}$ & & & & & \\
\hline $\begin{array}{l}\text { GS-20 - Aggregation of spatial entities and legislative } \\
\text { redistricting }\end{array}$ & $\mathrm{X}$ & $\mathrm{X}$ & & & & \\
\hline $\begin{array}{l}\text { GS-21 - Balancing security and open access to geospatial } \\
\text { information }\end{array}$ & & & $\mathrm{X}$ & & & \\
\hline GS-22 - Implications of distributed GIS\&T & & & $\mathrm{X}$ & & & \\
\hline
\end{tabular}




\begin{tabular}{|c|c|c|c|c|c|c|}
\hline & \multicolumn{6}{|c|}{ Frame } \\
\hline Topic & $\mathbf{A C}$ & IC & IV & RI & SC & SE \\
\hline GS-23 - Legal mechanisms for sharing geospatial information & & & $\mathrm{X}$ & & & \\
\hline GS-24 - Citizen science with GIS\&T & & $\mathrm{X}$ & $\mathrm{X}$ & & & \\
\hline GS-25 - Spatial decision support & & & & $\mathrm{X}$ & & \\
\hline KE-02 - Problem definition & & & & $\mathrm{X}$ & & \\
\hline KE-05 - Requirements analysis & & $\mathrm{X}$ & & $\mathrm{X}$ & & $\mathrm{X}$ \\
\hline KE-06 - Social, political, and cultural issues & & $\mathrm{X}$ & $\mathrm{X}$ & & & \\
\hline KE-07 - Feasibility analysis & & $\mathrm{X}$ & & $\mathrm{X}$ & & \\
\hline KE-08 - Data costs & & & $\mathrm{X}$ & $\mathrm{X}$ & & $\mathrm{X}$ \\
\hline KE-11 - Funding & & & & & & $\mathrm{X}$ \\
\hline KE-14 - Valuing and measuring benefits & & & $\mathrm{X}$ & & & \\
\hline KE-16 - Agency, organizational, and individual perspectives & & & $\mathrm{X}$ & & & \\
\hline KE-17 - Measuring costs & & & & & $\mathrm{X}$ & $\mathrm{X}$ \\
\hline $\begin{array}{l}\text { KE-18 - Data sharing among public and private agencies, } \\
\text { organizations, and individuals }\end{array}$ & & & $\mathrm{X}$ & & & \\
\hline KE-25 - GIS\&T training and education & & & & & & $\mathrm{X}$ \\
\hline KE-27 - Professional organizations & $\mathrm{X}$ & & & & $\mathrm{X}$ & $\mathrm{X}$ \\
\hline KE-28 - Publications & $\mathrm{X}$ & & & & $\mathrm{X}$ & $\mathrm{X}$ \\
\hline KE-29 - The geospatial community & $\mathrm{X}$ & & & & $\mathrm{X}$ & $\mathrm{X}$ \\
\hline KE-30 - The geospatial industry & & & & $\mathrm{X}$ & & \\
\hline KE-31 - Professional certification & $\mathrm{X}$ & & & & & \\
\hline KE-32 - Competence in GIS\&T knowledge work & $\mathrm{X}$ & & & & & \\
\hline PD-05 - Implementation tasks & $\mathrm{X}$ & $\mathrm{X}$ & & & & $\mathrm{X}$ \\
\hline PD-12 - Commercialization of GIS applications & & & $\mathrm{X}$ & & & \\
\hline PD-19 - GIS APIs & & $\mathrm{X}$ & & $\mathrm{X}$ & & $\mathrm{X}$ \\
\hline Total & 44 & 96 & 50 & 40 & 50 & 34 \\
\hline
\end{tabular}


Table 1. Snapshot of Appendix 1 included to illustrate the coding scheme employed during qualitative analysis and representative examples from the crosswalk process.

\begin{tabular}{|c|c|}
\hline ACRL Framework & GIS\&T Body of Knowledge \\
\hline \multirow{2}{*}{\multicolumn{2}{|c|}{ I. Authority is Constructed and Contextual }} \\
\hline A. Knowledge Practices & \\
\hline $\begin{array}{l}\text { 6. understand the increasingly social nature } \\
\text { of the information ecosystem where } \\
\text { authorities actively connect with one } \\
\text { another and sources develop over time }\end{array}$ & $\begin{array}{l}\text { GS-17: Evaluate the impact of geospatial technologies } \\
\text { (e.g., Google Earth) that allow nongeospatial } \\
\text { professionals to create, distribute, and map geographic } \\
\text { information. }\end{array}$ \\
\hline \multirow{2}{*}{\multicolumn{2}{|c|}{$\begin{array}{l}\text { II. Information Creation as a Process } \\
\text { B. Dispositions }\end{array}$}} \\
\hline & \\
\hline $\begin{array}{l}\text { 5. resist the tendency to equate format with } \\
\text { the underlying creation process }\end{array}$ & $\begin{array}{l}\text { FC-20: Demonstrate how different methods of data } \\
\text { classification for a single dataset can produce maps that } \\
\text { will be interpreted very differently by the user. }\end{array}$ \\
\hline \multicolumn{2}{|l|}{ III. Information Has Value } \\
\hline \multicolumn{2}{|l|}{ B. Dispositions } \\
\hline $\begin{array}{l}\text { 2. value the skills, time, and effort needed } \\
\text { to produce knowledge }\end{array}$ & $\begin{array}{l}\text { DC-21: Explain the ways in which metadata increases } \\
\text { the value of geospatial data. }\end{array}$ \\
\hline \multicolumn{2}{|l|}{ IV. Research as Inquiry } \\
\hline \multicolumn{2}{|l|}{ A. Knowledge Practices } \\
\hline $\begin{array}{l}\text { 3. deal with complex research by breaking } \\
\text { complex questions into simple ones, } \\
\text { limiting the scope of investigations }\end{array}$ & $\begin{array}{l}\text { AM-02: Outline the sequence of tasks required to } \\
\text { complete the analytical process for a given spatial } \\
\text { problem. }\end{array}$ \\
\hline \multicolumn{2}{|l|}{ V. Scholarship as Conversation } \\
\hline \multicolumn{2}{|l|}{ B. Dispositions } \\
\hline $\begin{array}{l}\text { 7. value user-generated content and evaluate } \\
\text { contributions made by others }\end{array}$ & $\begin{array}{l}\mathrm{CV}-24 \text { : Evaluate the effectiveness of a map for its } \\
\text { audience and purpose. }\end{array}$ \\
\hline \multicolumn{2}{|l|}{ VI. Searching as Strategic Exploration } \\
\hline \multicolumn{2}{|l|}{ A. Knowledge Practices } \\
\hline $\begin{array}{l}\text { 3. utilize divergent (e.g., brainstorming) and } \\
\text { convergent (e.g., selecting the best source) } \\
\text { thinking when searching }\end{array}$ & $\begin{array}{l}\text { KE-08: Identify potential sources of data (free or } \\
\text { commercial) needed for a particular application or } \\
\text { enterprise. }\end{array}$ \\
\hline
\end{tabular}


Table 2. Ratio comparing the number of topics aligned to the Framework to the total number of topics in each BoK 2.0 knowledge area (ranked highest to lowest).

\begin{tabular}{|c|r|r|r|}
\hline $\begin{array}{c}\text { Knowledge } \\
\text { Area }\end{array}$ & \multicolumn{1}{|c|}{$\begin{array}{c}\text { Aligned } \\
\text { Topics }\end{array}$} & \multicolumn{1}{c|}{$\begin{array}{c}\text { Total } \\
\text { Topics }\end{array}$} & $\begin{array}{c}\text { Alignment } \\
\text { Ratio }\end{array}$ \\
\hline DA & 16 & 16 & 1.00 \\
\hline CV & 29 & 32 & 0.91 \\
\hline GS & 22 & 25 & 0.88 \\
\hline FC & 24 & 34 & 0.71 \\
\hline DC & 13 & 20 & 0.65 \\
\hline CP & 8 & 13 & 0.62 \\
\hline KE & 17 & 33 & 0.52 \\
\hline AM & 29 & 58 & 0.50 \\
\hline DM & 21 & 43 & 0.49 \\
\hline PD & 3 & 16 & 0.19 \\
\hline Total & $\mathbf{1 8 2}$ & $\mathbf{2 9 0}$ & $\mathbf{0 . 6 3}$ \\
\hline
\end{tabular}


Table 3. Matrix depicting the number of learning objectives aligned to the Framework for each unique pairing of BoK 2.0 knowledge areas and ACRL frames.

\begin{tabular}{|c|c|c|c|c|c|c|}
\hline & \multicolumn{7}{|c|}{ Frame } \\
\hline $\begin{array}{c}\text { Knowledge } \\
\text { Area }\end{array}$ & AC & IC & IV & RI & SC & SE \\
\hline AM & 3 & 24 & 3 & 11 & 9 & 1 \\
\hline CP & 1 & 2 & 8 & 2 & 4 & 2 \\
\hline CV & 11 & 62 & 9 & 9 & 18 & 2 \\
\hline DA & 9 & 11 & 7 & 6 & 7 & 12 \\
\hline DC & 6 & 15 & 5 & 1 & 2 & 8 \\
\hline DM & 2 & 23 & 7 & 5 & 4 & 3 \\
\hline FC & 12 & 19 & 6 & 2 & 15 & 5 \\
\hline GS & 16 & 5 & 28 & 4 & 4 & 0 \\
\hline KE & 7 & 3 & 6 & 7 & 8 & 11 \\
\hline PD & 1 & 3 & 1 & 1 & 0 & 2 \\
\hline
\end{tabular}

